\begin{tabular}{lcc} 
e-makâlât & www.emakalat.com & ISSN 1309-5803 \\
\hline Mezhep Arasstırmaları Dergisi & 10, sy. 2 & (Güz 2017): 315-351 \\
\hline Journal of Islamic Sects Research & 10, no. 2 & (Fall 2017): 315-351 \\
\hline \multicolumn{2}{c}{ Hakemli Araştırma Makalesi } & Peer-reviewed Research Article
\end{tabular}

\title{
GÜNÜMÜZ İRAN ŞİILİĞINDE KUTSAL GÜN VE GECELER
}

Sacred Days and Nights in Contemporary Iranian Shiism

\author{
Habip DEMIR*
}

Öz

Mezhepler, belli bir coğrafyada ve zaman diliminde ortaya çıksa da farklı kültür ve havzalarla karşılaştıkça bulunduğu yerin kalıbını alarak gelişip farklılassmaktadir. Her din/mezhep için sembol ifade eden önemli zaman dilimleri mevcuttur. Zira bir mezhep toplumsal hayata ne kadar nüfuz ederse kalıcılığ 1 ve inandırıcılığı da o ölçüde artacaktır. Diğer bütün dinlerde/dini hareketlerde olduğu gibi İslam mezheplerinde de sosyal birlikteliği sağlamak, kutsalı güncel tutmak amaciyla özel önem verilen zaman dilimleri bulunmaktadir. Söz konusu kutsal zamanlara yapilan vurgunun en çok Șiilik'te olduğu görülmektedir. Şiiliğin kutsal gün ve gecelere verdiği önem mezhebin tarihsel süreçte yenilenerek güncellenmesini ve günümüze kadar toplum üzerinde etkinliğinin sürmesini sağlamıştır. Çalışmamiz günümüz İran'1 ve dolayısıla İmamiyye Sia'sı özelinde bir yıl boyunca kutsal kabul edilen gün ve geceler ile bunların önemini açıklamayı amaçlamaktadır. Ancak burada satır aralarında kalmıs ve sadece takvim yapraklarında gösterilen gün ve geceler değil, İran'ın dini hayatında gözle görülür etkisi olanları tercih edilmiştir.

Anahtar Kelimeler: İran, Şiilik, İmamiyye, Kutsal Zaman, Gün ve Geceler

\section{Abstract}

The sects emerge in a certain geographical region within a certain time period. However, when they encounter different cultures and basins, they develop and differentiate by taking the place where they are. There are important time periods for each religion/ religious movements, which are symbolic. The more persistence of a sectarian societal life, the more persistence and persuasiveness it will increase. As in all other religions/religious movements, there are also time periods in Islam that give special importance to keep social consensus among the members of the people and to keep them holy up to date. Among the Islamic sects, the emphasis on holy times seems to be mostly in Shiism. The importance of sacredness to holy days and nights has been renewed and renewed in the historical process of the sect, and it has continued to be active in society as much as the day. Our work aims to explain the importance of today's days and nights, which are considered holy for one year in Iran, and therefore the Shia of Imamiya. However, the lines between them stayed and were not only the days and nights shown on the calendar leaves, but those with visible effects in Iran's religious life were preferred. Keywords: Iran, Shiism, Imamiyya, Sacred Time, Day and Nights

* Yrd. Doç. Dr., Hitit Üniversitesi İlahiyat Fakültesi, İslam Mezhepleri Tarihi Anabilim Dall, habibdemir06@gmail.com

\begin{tabular}{ccc}
\hline Başvuru|Submission & Kabul|Accept & Yayın | Publish \\
18.11 .2017 & 18.12 .2017 & 30.12 .2017 \\
\hline DOI & &
\end{tabular}




\section{GİRIŞ̧}

Tarihte yer edinmiş bütün dinler/dini hareketler, ortaya çıktıkları ilk dönemin izlerini taşımakla birlikte tarihsel süreç içerisinde çeşitli toplumsal ve siyasal sâiklerin etkisiyle/baskısıly yenilenmek ve gelişmek zorunda kalmışlardır. Yeni olgulara ve toplumsal değişime ayak uyduramayan dini hareketlerin zaman içinde müntesiplerinin ihtiyaçlarına cevap veremez duruma gelerek yok olma sürecine girdikleri bilinen bir gerçektir. Dinin anlaşılma biçimi olarak değerlendirilen mezhepler için de durum bundan farklı değildir. Mezhepler, belli bir coğrafyada belli bir zaman diliminde ortaya çıkarlar. Ancak tarihsel süreçte farklı kültür ve havzalarla karşılaştıkça bulunduğu coğrafyanın kalıbını alarak gelişip farklılaşırlar. Bu bağlamda bir mezhebin geniş kitleler tarafından kabul edilmesi, onun farklı kültürlere eklemlenebilme yeteneğine bağlıdır.

Her din/mezhep için sembol ifade eden önemli zaman dilimleri bulunmaktadır. Dinler/mezhepler, bu zaman dilimleri aracılığıyla inananlarını ve taraftarlarını belli semboller etrafında birlesstirip, ortak sevgi ve hüzün paylaşımları sayesinde dinamizmlerini koruyarak hayatiyetlerini devam ettirmek isterler. İnançların ve bunların kurumsallaşmış hali olan dinlerin gelecek nesillere aktarılmasında bilgi boyutu önemli olmakla birlikte bunları kalıcı hale getirmede duygu ve görselliğin daha çok önem arz ettiği muhakkaktır. Bu nedenle dinlerin en önemli dayanağı olan "kutsal" kavramının somutlaşarak geniş halk kitlelerinin belirli ritüeller etrafında toplanması ve halkın tahayyülünde yer etmesi gerekmektedir.

\section{Mezheplerin Güncellenmesinde Kutsal Gün ve Gecelerin Önemi}

Mezheplerin nesiller arası aktarımı ancak sosyal hadiselerin bireylerin zihinlerinde güncellenmesiyle mümkün olabilir. Bir mezhep toplumsal hayata ne kadar nüfuz ederse kalıcılığ ve inandırıcılığı o ölçüde artacaktır. Mezhebin kalıcılı̆̆ında edebiyat/bilgi birikimi önemli olsa da toplumun en küçük yapıtaşlarına nüfuz edememiş bir mezhebin hayatta kalması mümkün değildir. Öyle ki geçmişten günümüze mezhep hareketleri ele alındığında sayıca az olmalarına rağmen müntesipleri arasında nesiller boyu devam eden bir bağ kurabilmiş 
mezheplerin yaşamaya devam ettikleri görülmektedir. Bunun aksine sadece bilgi boyutuyla kalan ve toplumsal tabana yayılamayan mezheplerin ise yok oldukları bilinmektedir. Bu bağlamda Şiiliğin "yaşayan bir mezhep" olması onun asırlar boyunca toplumla iç içe bulunmasının doğal bir sonucu olsa gerektir.

Dini ya da mezhebi sosyal hayatta etkin kılmanın en önemli araçlarından birisi kutsal zamanlardır. Gelmiş geçmiş bütün dinlerde "kutsal zaman" anlayışı birbirine paralellik arz etmektedir. Dinlerde kutsal zamanlara yapılan vurgu Misır, İran ve Hint medeniyetlerinin uzun geçmişleri boyunca izlenebilir. Bu medeniyet havzaları, sonradan ortaya çıkmış bütün dini hareketleri kutsal zaman algısı bakıminda da etkilemiştir. Eski Mısır'da Tanrılarla ilişkilendirilerek kutsallaştırılan çeşitli günlerin olduğu, ${ }^{1}$ Hinduizm'de Rama, Krişna gibi din büyüklerinin ve avatarların doğum günlerine verilen özel ilginin çeşitli dinler içerisinde farklı boyutlarda ve niteliklerde devam ettiğini söylemek mümkündür. ${ }^{2}$

Dinlerin belirli zamanları kutsallaştırma eğiliminde olmaları bizatihi zaman kavramının nasıl algılandığıyla ilgilidir. Antik dönemde dünyanın ezeli ve ebedi olduğu öngörüsüyle hareket eden filozoflara göre zaman doğrusal bir zeminde sonsuza kadar uzanmaktadır. Bu özelliğiyle zaman, sürekli bir değişimi ve gelişimi ortaya çıkarır. Ancak dindar insana göre zaman türdeş değildir. ${ }^{3}$ Ona göre dünya, yıllık olarak yenilenen döngüsel bir karaktere sahiptir. Yani yaratıcının elinden çıktığında sahip olduğu kökensel "kutsallığa" her yıl yeniden kavuşmaktadır. ${ }^{4}$ Böylece her seferinde "ilk an" in cosskusunu yaşama imkânına kavuşmuş olacaktır. Hem ilk ana dönme hem de kutsalın sonsuzluğunu sağlamak amaçlanır. ${ }^{5} \mathrm{Bu}$ bağlamda dinlerde özel önem verilen yeni y1l kutlamaları aslında evrenin her yıl yeniden yaratıldığına, saf ve temiz hale geldiğine olan inanç dolayısıyladır. Her

1 Mustafa Ünal, Dinlerde Kutsal Zamanlar (İstanbul: IQ Kültür Sanat Yayınlar1, 2008), 25.

2 Ünal, Dinlerde Kutsal Zamanlar, 28.

3 Mircea Eliade, Kutsal ve Dindışı. çev. Mehmet Ali Kılıçbay (Ankara: Gece Yayınları, 1991), 48.

4 Eliade, Kutsal ve Dindışı, 55.

5 Ünal, Dinlerde Kutsal Zamanlar, 18. 
yeni yılda evrenin yaradılışı taklit edilmekte, dünya yeniden yaratılmakta ve bunu yaparken aynı zamanda "Zaman" da yaratılmakta, ona yeniden başlanarak diriltilmektedir. ${ }^{6}$

Yeni yılın kutlanması dışında dinlerde bayram adı verilen ve yıllık olarak tekrarlanan kutsal günler de büyük önem arz etmektedir. Eliade, dinlerde bayram uygulamasıyla geçmişte yaşanmış efsanevi bir olayın kutlanması değil, onun yeniden güncelleştirilmesinin amaç edinildiğini belirtir. ${ }^{7}$ Böylece bayrama katılanlar tarihin belli döneminde kalmış efsanevi olayın çağdaşları haline gelmektedirler. Başka terimlerle ifade edildiğinde bunlar tarihsel zamanlarından -yani dindış1, kişisel ve kişiler arası olayların toplamı tarafından meydana getirilen zamandan- "ç1kmakta" ve her zaman aynı olan, ebediyete ait olan ilksel zamana kavuşmaktadırlar. ${ }^{8}$

İşte bu nedenle modern dönemde çeşitli meşguliyetler tarafından doldurulan ve sürekli bir akış halinde olan zaman, kutsal zamanlar ile bir süreliğine durdurulmakta böylece ilgi dine ya da mezhebe çekilmektedir. Bu ilgi, bir yandan kişiye ve topluma hayatın kargaşasından bir süreliğine de olsa uzaklaşma firsatı verirken; diğer yandan dinin/mezhebin kendini sürekli gündemde tutmasına yardımcı olmaktadir.

Diğer bütün dinlerde/dini hareketlerde olduğu gibi İslam'da da mensupları arasında sosyal birlikteliği sağlamak, kutsalı güncel tutmak amacıyla başta Ramazan ayı olmak üzere, bayram günleri, Kadir gecesi gibi özel önem verilen önemli zaman dilimleri bulunmaktadır. $\mathrm{Bu}$ zaman dilimlerinin dayanaklarını Kur'an ve hadislerde sıkça bulmak mümkündür. Örneğin kendisine başlı başına sûre ayrılmış da olan Kadir gecesinin bin aydan hayırlı bir ay olduğu, meleklerin o gece yeryüzüne indiğinden bahsedilmektedir. Bunun dişında ortak değer olarak Hz. Peygamber’in doğum yıldönümleri "Mevlit" adı altında uzunca bir süredir İslam âleminde çeşitli şekillerde kutlanmaktadir.

\footnotetext{
Eliade, Kutsal ve Dindışı, 85.

Eliade, Kutsal ve Dindışı, 61.

8 Eliade, Kutsal ve Dindışı, 67.
} 


\section{Şii Geleneğin Kutsal Zaman Algısı}

İslam mezhepleri söz konusu olduğunda zaman ve mekâna atfedilen kutsallaştırma olgusunun en açık örneğini İmamiyye/İsnâaşeriyye Şia'sında görmekteyiz. ${ }^{9} \mathrm{~Hz}$. Peygamber'den sonra Hz. Ali'nin ve on bir evladının açık ya da gizli bir nass yoluyla Müslümanların din ve dünya işlerini yönetmek üzere halife olarak görevlendirildiğini iddia eden İmamiyye mensupları, bugün dünya Müslümanlarının yaklaşık yüzde 12'lik kesimini oluşturmaktadır. Arkasında siyasi gücün hissedilmediği dönemlerde daha çok içe kapanık bir yapı arz eden İmamîler, iktidarın desteğini aldıkları dönemlerde toplumun bütün hücrelerine nüfuz edecek bir mezhebî kimliği inşa edebilmeyi başarmışlardır. Bunu gerçekleştirirken mezhebin en sık kullandığı yöntemlerden biri de tarihi olaylara duygusal açıdan fazlaca atıf yapması ve bu olaylar üzerinden bir tarih ve ideoloji inşa faaliyetini zihinlerde sürekli kılmasıdır.

Şii geleneğin kutsal zamanlara verdiği önemi, bu konuda oldukça yoğun bir birikimin görüldüğü dua literatürü üzerinden takip etmemiz mümkündür. Şii gelenek, ilk asırlardan itibaren dua eserlerine büyük önem vermiş, yıl, ay, hafta, gün ve hatta günün saatlerine özel duaların olduğu birçok eser meydana getirmiştir. ${ }^{10}$ Bunun yanında yılın önemli günlerini belirten takvim türü eserler de oluşturulmuştur. Bu eserler aracılığıyla tarihsel süreçte Şiiliğin kutsal kabul ettiği gün ve geceleri ve bunlar arasındaki değişimi takip etmek mümkündür. Geçmişten günümüze İmamiyye'nin özel önem atfettiği gün ve geceleri tespit eden çalışmalar mevcuttur. Bunlardan Şeyh Müfîd (ö. 413/1032) ve Şeyh Bahâî (ö. 1030/1621)'nin takvimleri Mehmet Ali Büyükkara tarafından yayınlanmış ve bu konuda önemli bir boşluğu doldurmuştur. ${ }^{11}$ Bunun yanı sıra Şii gelenek açısından oldukça

9 Şiilik hem bir çatı kavram hem de özel anlamda İmamiyye Şia'sı için kullanılmaktadır. Makalemiz boyunca Şia/Şii kavramıla İmamiyye Şia'sı kastedilmektedir.

10 Şii geleneğin dua literatürü ile ilgili bir çalışma için bkz. Resul Caferiyan, "Şîa'da Dua Edebiyatı", çev. Habip Demir, Iğdır Üniversitesi Ilahiyat Fakültesi Dergisi 6, (Ekim 2015): 209-237.

$11 \mathrm{Bu}$ eserlerden en önemli iki tanesi nessredilmiştir. Bkz. Mehmet Ali Büyükkara, İmâmiyye Şiası'na Göre Önemli Tarih, Gün ve Geceler (Şeyh Müfid ve Şeyh Bahâî’nin Takvimleri) (Çanakkale: 1999). 
önemli sayılan dua türü eserlerde özel gün ve gecelere sıklıkla değinilmiştir. Bu bağlamda makalemizde dua literatürünün en önemli eserleri arasında sayılan Şeyh Tûsî (ö. 460/1067)'nin Misbâhu'l-muteheccid, ${ }^{12}$ İbn Tâvûs (ö. 664/1266)'un el-ỉkbâlu'l-a'mâl, ${ }^{13}$ Allâme Meclisî (ö. 1110/1698)'nin Zâdu'l-meâd ${ }^{14}$ ve Şeyh Abbas Kummî'nin Mefâtihu'l-cinân'1 ${ }^{15}$ merkeze alınarak bu süreç takip edilmeye çalış1miştır.

Büveyhiler dönemine (932-1062) kadar siyasi baskılar nedeniyle içe kapalı bir yapı arz eden ve mezhebin sosyal boyutuna dair işaretleri gösteremeyen Şiiler, bu dönemle birlikte gerek ritüeller gerekse de farklı etkinliklerle toplumsal nüfuzlarını artırmışlardır. Çok eskiden beri idrak edilmelerine rağmen Bağdat'ta Büveyhiler'in desteğiyle resmi olarak başlatılan Gadir-i Hum ve Aşura merasimleri kısa sürede diğer bölgelere de yayılmıs, böylece mezhebin pratik boyutu ilk kez gözler önüne serilmiştir. Aşura matemi ve Gadir Bayramı şeklinde iki etkinlikle başlayan ve kendilerini Sünni gruplardan farkl1laştırmaya yarayan bu zaman dilimleri, Şiiler için aynı zamanda bir güç gösterisi anlamına gelmekteydi. ${ }^{16}$ Şiilerin toplumsal düzlemde hayata geçirdiği birçok bayram, tören gibi etkinlikler Sünni çoğunluğun da bunlara çeşitli şekillerde cevap vermesini doğurmuş ve bu dönemde ülkede Büveyhilerin de teşvik etmesiyle çok seslilik hâkim olmuştur. ${ }^{17}$

Şii geleneğe ait ilk dua metinlerinde bütün Müslümanlar tarafından ortak bir şekilde benimsenen özel zaman dilimlerine daha çok

12 Ebû Cafer Muhammed b. el-Hasen Şeyh Tûsî (ö. 460/1067), Misbâhu'l-muteheccid (Beyrut: Müessese-i Fikh-1 Şîa, 1411/1990).

13 Ali b. Musa İbn Tavus (ö. 664/1266), el-İkbalu bi'l-a'mali'l-hasene fìmâ ya'melu merraten fi's-sene, thk. Cevad Kayyûmî İsfehânî (Kum: Mektebu'lA'lâmi'l-İslâmî, 1414).

14 Muhammed Bâkır b. Muhammed Takî el-Meclisî (ö. 1110/1698), Zâdu'lmeâd, thk. Alauddin A'lamî (Beyrut: Müessesetu el-A'lamî li'l-Matbûât, 1423).

15 Şeyh Abbas Kummî, Mefâtîhu'l-cinân (Kum: Âyin-i Dâniş, 1386/2007).

16 Ahmet Güner, "Büveyhiler Dönemi ve Çok Seslilik", Dokuz Eylül Üniversitesi İahiyat Fakültesi Dergisi 12, (1999): 56-57.

17 Güner, "Büveyhiler Dönemi ve Çok Seslilik", 56. 
vurgu yapıldığını görmekteyiz. ${ }^{18}$ Bunun yanı sıra Şiiler için özel anlam ifade eden ve kendilerine has olan Așura, Gadir ve Mübâhele günlerine yapılan vurgularla Şii toplumunun farklılaşmaya başladığ görülmektedir. Diğer yandan Şiilik, farklı coğrafyalara özellikle Hint coğrafyasına yayılması neticesinde yeni kültürleri de bünyesine adapte etmiştir. Bâtınî dünya görüşünün egemen olduğu Hint dinlerinin kutsal zamanlara diğer dinlere nazaran oldukça fazla yer vermesi Şiiliğin kutsal zaman algısını da değiştirmiş olmalıdır. Örneğin Hindistan'da bir velinin ölüm yıldönümü olarak anılan ve "Urs" ad1 verilen etkinlikler yanında çeşitli din büyüklerini anmaya yönelik çok sayıda etkinliğin de olduğu bilinmektedir. ${ }^{19}$ Özellikle Safeviler'in İran'da yönetime gelmesi ile birlikte Şiiliğin bu bölgeyle daha yakın temas kurması, önceleri sınırlı sayıda kutlanan gün ve gecelerin sonraki asırlarda on iki imamın her birinin doğum ve ölüm yıldönümlerini de içine alacak şekilde genişletildiği anlaşılmaktadır. ${ }^{20}$ Safeviler dönemindeki kutsal gün ve gecelerin devletin resmi politikası sonucu artırılmış olduğunu vurgulayan Ali Şeriati bu olguyu Hristiyanlığın tesirine bağlamaktadır. ${ }^{21}$ Şeriati bu olguyu Hristiyanlığın tesirine

18 Bu zaman dilimleri arasında Recep, SSaban, Ramazan ve Zilhicce gibi önemli aylar ve bunlar içerisinde zikredilen Namaz, Hac, Oruç, Sadaka gibi ibadetler yer almaktadir.

19 Annemarie, Schimmel, Tanrinın Yeryüzündeki İşaretleri (İstanbul: Kabalc1 Yayınlar1, 2004), 105.

20 Schimmel, Tanrinın Yeryüzündeki İşaretleri, 106.

21 Şeriati bu konuda şu tespite yer vermektedir: "Şia, Âli Bûye yönetiminin kısa dönemi ve Serbedariler gibi geçici yönetimler dışında hiçbir zaman bağımsız olamadığı ve toplumsal görünüm kazanamayarak takiyye altında yaşadığı için henüz nasıl ve ne gibi toplu formlarda ve genel görünümlerde görüneceğini bilemez. Toplumsal sembolü, alametleri ve törenleri yoktur. Safevi rejiminin bunlara ihtiyacı olduğu sırada bir şeyler yapmalıdır. Bu iş çok basitçe gerçekleşti. Resmi bir vezirlik makamı oluştu. Ravza Okuma İşleri Veziri adıyla bu işleri düzenlemek için bir kişi görevlendirildi....Ravza okuma ve Taziye İşleri Veziri, Batı Avrupa'ya gitti (ki o sıralarda Safeviler'in onlarla çok yakın ve gizemli ilişkileri vardı) ve oranın dini törenleri ve teşrifatlarıyla ilgili olarak inceleme ve araştırmalarda bulundu. Hristiyanlığın gelenekler, toplu dini törenler, gösteriler, programlar, Mesih'in, havarilerin ve Hristiyan tarihinin şehitlerinin musibetlerini dile getirme gibi unsurlardan birçoğunu, ayrıca bu dini mahfillere ve kiliseye özgü dekorları, bu törenlere özgü araçları iktibas ederek hepsini İran'a getirdi. Burada, Safevi rejimine bağlı ruhanilerin yardımıyla, bu formları ve gelenekleri Şiiliğe, Şiilik tarihine ve İran'ın dini ve ulusal çıkarla- 
bağlıyor olsa da bu tür tesirlerin Hristiyanlığa bâtınî zihniyetin egemen olduğu Hint kültür havzasından taşındığını düşünmekteyiz. Her ne sebeple olursa olsun Safeviler döneminde Şiiliğin toplumsal tabana daha fazla nüfuz etmesinin kutsal gün ve geceler yoluyla gerçekleştiğini söylememiz mümkündür.

\section{Günümüz İran'1nda Önemli Gün ve Geceler}

Safeviler döneminde yaygınlaşmaya başlayan ve devlet desteğiyle toplumsal tabana yayılan etkinliklerin günümüz İran'inda da artarak devam ettiği görülmektedir. Öyle ki imamların ya da mezhebin önemli karakterlerinin doğum veya ölüm yıldönümünün birden fazla tarih olarak kaydedilmesi bu etkinliklerin yıl boyu devam etmesine yol açmaktadır. Bu sayede yılın bütün aylarında mezhebi pratikler yoluyla halkın muhayyilesinin canlı tutulmasına yardımcı olunmaktadır.

Şii geleneğin yapısı açısından yılın neredeyse bütün günlerinin herhangi bir bakımdan da olsa önem arz ettiği ve bunların da bu amaçla hazırlanmış çeşitli takvimlere yansıdığı bilinmektedir. Ancak biz, satır aralarında kalmış ve sadece takvim yapraklarında gösterilenleri değil, İran'in mevcut koşullarında toplumsal olarak anlamı olup bir şekilde kutlanan ya da anılan ve çoğunluğunu bizzat gözlemlediğimiz gün ve geceleri Hicrî takvimdeki sırasına uygun olarak ele almaya çalışacağız. Bu bağlamda amacımız, sadece İran'da pratik değeri olan ve herhangi bir şekilde kutlanan ya da özel anma programı yapılan günleri tespit edip bir mezhebin nasıl yaşatıldığını ortaya koymaktır.

Günümüzde resmi mezhep olarak İmâmiyye/İsnâaşeriyye'yi kabul eden İran İslam Cumhuriyeti, özellikle 1979'da gerçekleştirilen "İslam Devriminden" sonra dini gün ve gecelere çok daha fazla önem

rına uyarladılar. O, Avrupa Hristiyan kalıplarına İranlı Şii içeriği kazandırd1lar. Öyle ki ansızın İran'da, hiçbir zaman ne İran milletlerinde ne İslam dininde ne de Şia mezhebinde geçmişi bulunan tam anlamiyla yeni semboller, törenler ve gösteriler oluştu. Taziye, dini kahramanların canlandırılması, sancak, kubbe, tahtırevan, perdedarlık, kilit kapama, zincir vurma, kılıç vurma, müzik, zil çalma, taziye okuma ve "muscibet hanlık" ve "toplu ağlaşma" gibi özel ve yeni protokollük törenlerin hepsi şekil olarak Hristiyanlıktan alınmıştır. Ona aşina olan herkes, bunun taklit olduğunu rahatlıkla teşhis edebilir." Ali Şeriati, Ali Şiası Safevi Şiası, çev. Hicabi Kırlangıç (Ankara: Fecr Yayınları, 2011), 161-162. 
vererek bunları anma ve kutlama programlarını devlet kontrolü altına almıştır. Bunun için özel bir daire kurularak bu etkinliklerin yurt çapında koordine edilmesi sağlanmıştır. Bu bağlamda günümüz İran'inda mevcut gün ve gece programlarının bizzat devlet tarafından şekillendirildiğini ve yaşatılması için özel gayret gösterildiğini söylemek mümkündür.

\section{MUHARREM}

Hicri takvimin ilk ayı olan Muharrem, yalnızca Şii gelenek açısından değil bütün Müslüman toplumu için de önem arz eden bir zaman dilimidir. İran söz konusu olduğunda Muharrem ayı, gerek yazılı edebiyatın gerekse görselliğin doruk noktasına çıktığı dini günlerin en görkemlisi ve etki bakımından en kuvvetlisidir. Bu ay, Şiiliğin gelişip kökleşmesi ve görünür hale gelmesi açısından önemli olaylara sahne olmuştur. Bunların en önemlisi de bilindiği üzere Hz. Hüseyin ve ailesinden yaklaşık 70 kişinin Emevi ordusu tarafından şehit edildiği Kerbelâ hadisesidir. Ancak Şii gelenek açısından 1 Muharremle başlayıp 20 Safer'e kadar süren 50 günlük dönem, Kerbelâ hadisesinin yanında bununla bağlantılı başka taziye günlerinin de bu sürece eklemlendiği oldukça geniş tutulmaya özen gösterilmiş bir zaman dilimi haline gelmiştir. Aşura olarak isimlendirilen Hz. Hüseyin’i ve Kerbelâ'yı anma günü etkinliklerinin tarihi eskilere dayanıyorsa da resmi olarak devlet eliyle ilk kez onuncu asrın ilk yarısında Büveyhiler'in Bağdat'ı ele geçirmelerinden sonra 352/963 yılında başladığı bilinmektedir. ${ }^{22}$ Kerbelâ hadisesi, Şiiler açısından sadece tarihin belirli bir döneminde meydana gelmiş bir olay olarak görülmemektedir. Bu olay, süreç içerisinde Şiiler tarafından çeşitli rivayetlerle zenginleştirilerek insanlığın bütün bir tarihi tecrübesini kapsayacak bir şekilde adeta evrensel tarihin merkezine yerleştirilmiştir. Yani Hz. Hüseyin'in bu süreçte çektiği acılar ve şehadeti anlatısı Hz. Adem'den itibaren birçok önemli/kutsal şahıs etrafında dile getirilen hikayelerle birlikte

22 Ahmet Güner, "Büveyhiler Döneminde Bağdat'ta Kerbelâ/Aşure, Gadir Humm ve Benzeri Şii Uygulamaları”, Çeşitli Yönleriyle Kerbelâ (Tarih Bilimleri I), (Sivas: 2010): 325. 
sunulmaktadır. ${ }^{23}$ Kerbelâ'nın yüzyılllar içerisinde Şii gelenek tarafından "seçilmiş bir travma" olarak kabul edilip sürekli gündemde tutulması, olayı artık tarihsel gerçeklikten kopararak mitolojik bir karaktere büründürmüştür. ${ }^{24}$ Bunun izlerini günümüz İran'inda fazlasiyla görmek ve hissetmek mümkündür. ${ }^{25}$

1 Muharrem-26 İran genelindeki bütün cami, mescit, Hüseyniye ${ }^{27}$ ve tekkelerde Matem ayının (Mâh-1 Mâtem), diğer bir deyişle "Eyyâm1 Hüseynî"nin 28 başlangıcıdır. Ay başlamadan İran'ın bütün şehirlerinde siyah bayraklar, flamalar, afişler vb. hazırlanarak şehrin önemli yerlerine ve evlerin girişine asılır. Bu günden itibaren gerek

23 Schimmel, Tanri'nın Yeryüzündeki İşaretleri, 106.

24 Hasan Onat, "Kerbelâyı Doğru Okumak", Akademik Orta Doğu, $2 / 1$ (2007): 3-4.

25 Kerbelâ olayının güncele taşınan yorumları için bkz. Mehmet Ali Büyükkara, "Çağdaş Şîa Düşüncesinde Kerbelâ'nın Problemli Mirası: İmam Hüseyin Kazanmak İçin mi Yoksa Canını Feda İçin mi Ayaklandı?”, Çeşitli Yönleriyle Kerbelâ (Tarih Bilimleri I), (Sivas: 2010): 383-408; Metin Bozan, "Şii-İmami Kaynaklarda Kerbelâ'nın Menkâbevi Anlatımı, Çeşitti Yönleriyle Kerbelâ (Tarih Bilimleri I), (Sivas: 2010): 477-492.

26 Şeyh Tûsî’nin yılın ay ve günlerine özel duaları derlediği eserinde Muharrem ayının ilk dokuz gününe ait herhangi bir duaya yer vermediği görülmektedir. Muharrem ayının birinci günü Allah'ın Zekeriya (a.s.)'nın duasını kabul etmesi, üçüncü günü Yusuf (a.s.)'in kuyudan kurtulmas1, beșinci günü Musa (a.s.)'ın denizi geçmesi, yedinci günü Allah'ın Musa (a.s.) ile Tur dağında konușması, dokuzunu günü Yunus (a.s.)'ın balığın karnından çıkması olarak verilmektedir. Bu bilgi dikkate alınırsa, Şii geleneğin matem algısının günümüzdekinden farklı olduğu anlașılmaktadır. (Bkz. Seyh Tûsî, Misbâhu'l-muteheccid, 2: 771.) Aynı yaklaşım İ̉bn Tâvûs'un eserinde de görülmektedir. (Bkz. İbn Tâvûs, el-İkbâlu'l-a'm'al, 3: 20-63.)

27 Safeviler dönemiyle birlikte İran'da yaygın olarak bulunan tekkelerin yap1sından etkilenerek Hz. Hüseyin'e atıfla kurulan, başlangıçta yalnızca Muharrem ayındaki matem için faaliyet gösteren, bugün ise bütün dini ritüellerin icra edildiği ve hemen hemen bütün mahallelerde bulunan ve halk tarafından yaptırılan önemli bir mekandır. Mescitler sadece dini bakımdan ibadet merkezi olarak düşünülmüş iken Hüseyniyeler, mezhebin sosyal hayata doğrudan yansıtıldığı, hem sosyal hem de siyasal bir araç olarak görülüp desteklenmiştir. (Bkz. Mesud Nârî Kummî, "Olgûhâ-yı Kâlbedi-yi Hüseyniyehâ: Rîșehâ ve Tehavvulât", Hüner ve Mimarî, 9 (1395/2016): 26-28).

28 Abdulhüseyin Nîşâbûrî, Takvîm-i Şĩa (Kum: İntişarat-1 Delîl-i Mâ, 1391/2012), 15 
sokaklarda gerekse insanların toplu olarak bir arada bulunduğu bütün ortamlarda mersiyeler okunarak günün anlamıyla ilgili hatıralar hatırda tutulmaya ve canlandırılmaya çalışılır.

9 Muharrem- "Tâsûâ-i Hüseynî" adıyla anılan gündür. ${ }^{29} \mathrm{~Hz}$. Hüseyin ve beraberindekilerin Kerbelâ'da muhasara altına alındığı güne nispetle bu isimle bilinir. ${ }^{30} \mathrm{Bu}$ günde matem merasimleri en coşkulu günlerinden birini yaşar. Meddahlar ${ }^{31}$ bu günde daha çok $\mathrm{Hz}$. Ali'nin oğlu ve Kerbelâ vakası sırasında şehit olan Ebu'l-Fazl Abbas ${ }^{32}$ hakkında mersiyeler okuyarak onun kahramanlıkları ve cesaretini hatırlatır. Bazı meddahlar ve vaizler, halkın cosskusunu artırmak ve bu günü daha da anlamlandırmak adına 9 Muharrem'i Ebu'l-Fazl'ın şehadet günü olarak anmaktadır. Ancak onun 10 Muharrem'de şehit edildiği İran'ın resmi kaynakları tarafından da dile getirilmektedir. ${ }^{33}$

29 Şeyh Abbas Kummî, Mefâtîhu'l-cinân, 500.

30 Gün ile ilgili Şii hadis literatüründe Cafer-i Sadık'tan nakledilen "Hüseyin ve ashabı Tâsûâ günü muhasara altına alındı." şeklinde bir rivayet mevcuttur. (Bkz. Ebû Cafer Muhammed b. Yâkub el-Kuleynî (ö. 328/939), Usûlu'l-kâfî, thk. Ali Ekber el-Gaffârî (Tehran: Dâru'l-Kütübi'l-İslâmiyye, 1407/1986), 4: 147.$)$

31 Meddah, İran'da dini gün ve gecelerde mersiye okuyan ve halkı ağlatan kişilere verilen addır. Meddahların bu görevi icra etmeleri, kendilerine İran genelinde oldukça popülerlik kazandırmış, onları ülkenin dini, sosyal ve hatta siyasî hayatında etki gücü olan bireylere dönüştürmüştür.

32 Hz. Ali'nin Ümmü'l-Benîn adlı hanımından olan dört oğlundan biridir. Kerbelâ olayları sırasında Hz. Hüseyin'in sancağını taşımış, cesareti ile ün salmış bu sayede "Benî Hâşim'in Ay'ı" lakabıyla anılmıştır. Kerbelâ vakası sırasında $\mathrm{Hz}$. Hüseyin ve yanındakilere su getirme görevi verilmesinden ötürü "es-Sekâ" lakabı da verilmiştir. (Bkz. Ali b. el-Hüseyin Ebu'l Ferec el-İsfehânî (ö. 356/966), Mekâtilu't-talibiyyîn (Beyrut: Dâru'l-Murtazâ, 1430/2009), 6061; Ebû Nasr Sehl b. Abdullah el-Buhârî (ö. 4./10. asır), Strru's-silsileti'l-aleviyye fì ensâbi's-sâdâti'l-aleviyye, thk. Seyyid Mehdî Recâî (Kum: 1389/2011), 131; Necmeddin Ebi'l-Hasan Ali b. Muhammed b. Ali b. Muhammed el-Alevî el-Ömerî (ö.466/1073), el-Mecdî fì ensâbi't-tâlibiyyîn, thk. Ahmed el-Mehdevî ed-Dâmeğânî (Kum: Mektebetü Âyetullah Mar'aşî Necefi, 1380/2001), 193-196; Ebû'l-Hasen Ali b. Ebî'l-Kâsım b. Zeyd İbn Funduk (ö. 565/1169), Lubâbu'l-ensâb ve'l-elkâb ve'l-a'kâb, thk. Seyyid Mehdi erRecâî (Kum: Mektebetu Ayetullah Mar'aşî Necefî, 1385/2007), 337; Ebû Talib İsmail b. Hüseyn Hüseyni el-Mervezî (ö. 614/1217'den sonra), el-Fahrî fî ensâbi't-tâlibiyyîn, thk. Seyyid Mehdi er-Recâi (Kum: Mektebetü Âyetullah Mar'aşî Necefi, 1385/2007), 169.)

33 http:// شهادت_حضرت_ابو الفضل_العباس-_www.hawzah.net/fa/occation/view/48956 عليه_السلام (Erişim: 21 Eylül 2017) 
10 Muharrem 61 - "Âşûra" günü. Hz. Hüseyin ve yanında bulunan 72 kişinin Emeviler tarafından şehit edildiği ve ailesinin esir alındığ gündür. Bu günde matem merasimleri zirvesine ulaşır. Şiiler, bu günü yâd etmek adına ikindi vaktine kadar su hariç bir şey yememeye dikkat ederler. Yenilecekse bile lezzetli yemekler tercih edilmez. Şeyh Bahâî, bu günde oruç tutmanın müstehab olduğunu ancak bu orucun hakiki bir oruç olmayıp hüznün verdiği meşguliyetten dolayı yemeyi ve içmeyi terk etmekten ibaret bir oruç olduğunu ifade etmektedir. Bu amelin Allah'a yaklaşma niyetiyle ve iftarının ise ikindiden sonra olduğunu belirtmektedir. ${ }^{34}$ Bunların yanı sıra İran'da ikindi vaktine doğru evlerde bir çeşit tatlı ikram edilmektedir. ${ }^{35}$

12 Muharrem 94- "Şehâdet-i İmam Seccâd (a.s.)". Şia'nın dördüncü imamı olarak kabul edilen Ali b. Hüseyin Zeyne'l-Âbidin'in vefat ettiği gündür. ${ }^{36}$ Başka bir rivayete göre 24-25 Muharrem olduğu

34 Büyükkara, Önemli Tarih, Gün ve Geceler, 49-50; Meclisî, Zâdu’l-meâd, 233234; Daha erken dönem müelliflerinden İbn Tâvûs, 10 Muharrem gününde bu şekilde farklılaşmış bir oruç türünden bahsetmemekte, genel kabullere göre $\mathrm{Hz}$. Peygamber'in 9 ve 10'unda tutulmasını tavsiye ettiği nafile oruç hakkında bilgi vermektedir. (Bkz. İbn Tâvûs, el-İkbâlu'l-a'm'al, 3: 50-55); Ülkemizdeki Alevî-Bektâşîlerce tutulan 12 günlük Muharrem orucunun İran'da karşılığı bulunmamaktadır.

35 Her ne kadar Türkiye'deki Așure adı verilen tatlının yenilmesi Şiiler tarafından Hz. Hüseyin'in çektiği acılara bir saygısızlık olarak nitelendirilip Sünni toplum eleştirilse de İran'da böyle bir ikramla karşı karşıya kalmak bizi şaşırtmiştır.

36 Şeyh Abbas Kummî, Mefâtîhu'l-cinân, 508; Ali b. Hüseyin, hicri 94 yılında 57 yaşında Medine'de vefat etmiştir. Normal bir şekilde öldüğü bilinen Ali b. Hüseyin'in de öldürüldüğü vurgulanmaktadır. Şii literatürde bütün imamlar şehit kabul edilmektedir. İlk dönem kaynaklarında bazı imamların şehit olmadıkları, normal yolla öldüklerine dair ciddi kayıtlar bulunmasına rağmen İran'da şehadet vurgusu güçlü bir şekilde devam etmektedir. Konu hakkında ayrıntılı bir çalışma için bkz. Mehmet Ali Büyükkara, "Kerbelâdan İnkılaba: İmami-Şii Şehadet Düşüncesi ve Problemleri", Ankara Üniversitesi İlahiyat Fakültesi Dergisi XLIII, sy. 2 (2002): 211-247. 
da söylenmektedir. ${ }^{37}$ Her iki tarih de kabul edilmekle birlikte $12 \mathrm{Mu}-$ harrem daha revaçtadır. ${ }^{38}$ Minberlerden yapılan bir iki hatırlatma d1şında, belki de Kerbelâ anmalarının etkisinin devam etmesinden ötürü etkili geçmemektedir.

\section{SAFER ${ }^{39}$}

5 Safer 61- "Şehâdet-i Hazret-i Rukayye (s.a.)". Hz. Hüseyin'in Rukayye adlı kızının vefat ettiğine inanılan gündür. ${ }^{40}$ Rivayetlere göre Kerbelâ'da babasıyla birlikte bulunmuş ve sonrasında esir edilerek önce Kufe'ye, ardından Şam’a götürülenler arasında yer almış ve orada vefat etmiștir.

7 Safer 127/128 (?)- "Velâdet-i İmam Musa Kazım (a.s.)". Şia'nın yedinci imamı olarak kabul edilen Musa b. Cafer el-Kâzım'ın doğum günü olarak kutlanmaktadır. ${ }^{41}$

20 Safer- "Erbaîn-i Hüseynî"42. Hz. Hüseyin'in şehit edilişinin 40. gününe verilen özel isimdir. Bu gün matem merasimleri sona ermek-

37 Yukarıda anılan tarihler dişında 18 Muharrem, 19 Muharrem ve 1 Safer tarihleri de dile getirilmektedir. (Bkz. Nîşâbûrî, Takvîm-i Şîa, 42); Şeyh Müfid'in takviminde Ali b. Hüseyin'in vefat1 25 Muharrem 94 olarak kaydedilmektedir. Büyükkara, Önemli Tarih, Gün ve Geceler, 30; Ancak Seyh Bahâî 12 Muharrem tarihini kabul etmektedir. Büyükkara, Önemli Tarih, Gün ve Geceler, 50).

38 Şeyh Abbas Kummî, Muntehe'l-â'mâl, tsh. Musevî Damegânî (Tehran: İntişârât-1 Peyâm-1 Âzâdî, 1390/2011), 2: 69.

39 Şeyh Tûsî, Safer ayında sadece "Erbaîn" olarak bilinen güne özel bir dua nakletmektedir. Günümüzde değer verilen diğer günlerin isimlerini zikretmemektedir. Şeyh Tûsî, Misbâhu'l-muteheccid, 2: 787-790.

40 İlk dönem Şii kaynaklarında Hz. Hüseyin'in Rukayye adlı bir kızının olduğu ile ilgili şüpheler mevcuttur. Ali b. İsa b. Ebi'l-Feth el-İrbilî (ö. 693/1293), Keșfu'l-gumme fi ma'rifeti'l-eimme (Beyrut: Dâru'l-Edvâ, 1405/1985, II:216; İbn Funduk, bu isimde bir kızından bahsetmemektedir. Lubâbu'l-Ensâb, 1: 350 .

41 Șeyh Abbas Kummî, Mefâtîhu'l-cinân, 509; İmam Kazım'ın doğum tarihinin Zilhicce ayının son günü olduğu da rivayet edilir. Nîşâbûrî, Takvîm-i Şîa, 60.

42 Tespit edebildiğimiz kadarıyla Erbain gününün Şii literatürdeki ilk yans1ması Şeyh Tûsi ile başlayıp İbn Tâvûs ile devam ettirilmiștir. Onun dönemine kadar Erbain'e özel bir anlamın verilmediği görülmektedir. İbn Tâvûs'un bu hususu zikretmesi kendisinden sonra gelenleri de etkilemiș ve bugüne özel bir anmanın fazileti literatüre girmiștir. İbn Tâvûs, el-İkbâlu'l- 
tedir. Yaklaşık on gün önceden İran'dan çok sayıda kişi, Erbaîn’i Kerbelâ'da geçirebilmek amaciyla büyük törenlerle uğurlanır. Hac organizasyonlarını andırır derecede yoğun katılımın yaşandığı bu günde, özel uğurlama merasimleri yapılır. Kerbelâ'yı ziyaret eden bu kişilerin ziyaretleri sonrası evlerinin önüne onun Kerbelâ'yı ziyaret ettiğini belirten afişler asılır. Tıpkı Hac vazifesini yapanlarda olduğu gibi bu kişilerin evleri yoğun bir ssekilde ziyaret edilir. Şiiler arasında Erbaîn ziyaretinden dönen bu kişilerin evlerini ziyaret etmemek ve onlar tarafından dağıtılan ikramları almamak ayıplanacak bir davranış olarak görülür. Bu gün İran'da aynı zamanda resmi tatildir.

Şii takvimlerde bu gün, sahabeden Câbir b. Abdullah el-Ensarî'nin ${ }^{43} \mathrm{~Hz}$. Hüseyin'in kabrini ziyaret ettiği ve Hz. Hüseyin'in ailesinin Şam'dan Medine'ye giderken Kerbelâ'ya vardıkları gün olarak da yâd edilir. ${ }^{44}$ Okunan mersiyelerde bu iki ziyarete sıkça atıf yapılmaktadir.

28 Safer 11- "Rihlet-i Peygamber (a.s.)"45 ve "Şehâdet-i İmam Hasen-i Müctebâ (a.s.) (h. 50) ${ }^{46 ” . ~ H z . ~ P e y g a m b e r ’ i n ~ v e f a t ~ e t t i g ̆ i ~ g u ̈ n d u ̈ r . ~}$

a'm'al, 3: 98-104; Meclisî, Zâdu'l-meâd, 248; Şeyh Abbas Kummî, Mefâtîhu'lcinân, 509; Hasan el-Askerînnin şöyle dediği rivayet edilmiştir: "Müminin alameti beştir: Günlük 51 rekat namaz, Erbain ziyareti, Yüzügü sağ ele takmak, alnı toprağa koymak ve yüksek sesle Bismillahirrahmanirrahim demek." Şeyh Tûsî, Misbâhu'l-muteheccid, 2: 788; Muhammed b. Hasan Şeyh Hurr Âmulî (ö. 1104/1692), Vesâilu'ş-Şîa, thk. Müessesetü Âli'l-Beyt Aleyhisselam (Kum: 1409/1988), 14: 478.

$43 \mathrm{~Hz}$. Peygamber'den en çok hadis rivayet eden sahabeler arasındadır. Hz. Ali'nin vesâyeti, müminler üzerindeki otoritesi, "sırât-1 müstakîm"in o olduğu, on iki imamın dindeki yeri gibi Şii itikadının önem verdiği birçok rivayeti nakleden önemli bir otorite olarak kabul edilmektedir. M. Yaşar Kandemir, "Câbir b. Abdullah", Türkiye Diyanet Vakfı İslam Ansiklopedisi (İstanbul: TDV Yayınları, 1992), 6: 531.

44 Şeyh Müfid bu günü 20 Safer, Şeyh Bahâî ise 19 Safer olarak kaydetmektedir. Büyükkara, Önemli Tarih, Gün ve Geceler, 54; Şeyh Tûsî de 20 Safer tarihini kabul etmektedir. Şeyh Tûsî, Misbâhu'l-muteheccid, 2: 787.

45 Meclisî, Zâdu'l-meâd, 279; Şeyh Abbas Kummî, Mefâtîhu'l-cinân, 509; Bazı Şii kaynaklarında Hz. Peygamber'in de zehirlenerek şehit edildiğine dair rivayetler vardır. Nîşâbûrî, Takvîm-i Şîa, 76.

$46 \mathrm{~Hz}$. Hasan'ın vefat tarihi ile ilgili ikinci bir rivayet 7 Safer günü olduğuyla ilgilidir. Ancak 28 Safer daha meşhurdur. Şeyh Müfid'in takviminde 27 veya 28 Safer olarak zikredilmektedir. Büyükkara, Önemli Tarih, Gün ve Geceler, 32; Nîşâbûrî, onun vefat tarihini 7 Safer olarak vermekte ancak ulemanın 
Resmî tatildir. Aynı zamanda Şia'nın ikinci imamı olarak kabul edilen Hz. Hasan'in, hanımı Ca'de tarafından Muaviye'nin yönlendirmesiyle zehirlenme sonucu vefat ettiğine inanılan gündür. Şii tarih yazımında Muaviye'nin kendine mahsus bir yerinin olmas1, bu günün onu kötülemede bir araç olarak kullanılmasını da kolaylaştırmıştır. Hz. Peygamber'in vefatından çok, Hz. Hasan'ın zehirlenmesi olayı özel bir ilgiyle anlatılır ve dinlenir. Bu günde şehrin birçok yerinde meddahlar, Muaviye'nin yaptığı hileleri ve imamın zehirlenişini etkili bir dille anlatırlar. Hatta kimi tiyatro oyunlarında Muaviye'nin çirkin bir yaratığa benzetilerek bütün kötülüklerin kaynağ1 şeytanla özdeşleştirildiği gözlenmiştir. Bu tür tiyatro oyunları sahnelendiğinde seyircilerin Muaviye karakterini canlandıran oyuncuyu her söze girişinde yuhalaması, Şiilerin tarihle ne kadar iç içe yaşadıklarını göstermesi açısindan dikkate değer bir manzara olarak görülmüsstür. ${ }^{47}$

30 Safer 203- "Şehâdet-i İmam Rizâ (a.s.)". 48 Şia'nın sekizinci imamı olarak kabul edilen Ali b. Musa er-Rıza'nın Me'mun tarafından zehirlenerek öldürüldüğüne inanılan gündür. ${ }^{49}$ Ali er-Rızâ, Şii imamlarından İran'da kısa süre de olsa yaşayan ve burada vefat eden tek kişidir. Onun varlığı hem yaşadığı dönemde hem de vefatının ardından türbesi etrafında geliştirilmiş yoğun literatürün etkisiyle İran için son derece önemlidir. Meşhed şehrinde bulunan türbesi, Kerbelâ'dan sonra dünya genelindeki Şiiler tarafından en çok ziyaret edilen ikinci

ekserince 27 Safer tarihinin daha doğru olduğunu belirtmektedir. Nîşâbûrî, Takvîm-i Şìa, 60.

47 Bu güne özel olarak 2013 yılında Kum şehrinde izlediğimiz bir tiyatro oyununda halkın olayın canlılığını zihinlerinde yaşatmaları ve duygusal tepkileri bizzat gözlenmiştir.

48 Şeyh Müfid, takviminde bu günü 23 Zilkade olarak verse de kendi yazdığ 1 diğer eseri el-İş̧ad'da imamın Safer ayı içinde vefat ettiğini kaydetmektedir. Güvenilir kaynakların kaydına göre İmam, Safer ayı içinde vefat etmiştir. Büyükkara, Önemli Tarih, Gün ve Geceler, 20; Meclisî, bu tarihi 17 Safer olarak kaydetmektedir. Muhammed Bâkır b. Muhammed Tâkî el-Meclisî (ö.1110/1698), Bihâru'l-envâr, thk. Heyet (Beyrut: Dâru İhyâi't-Turâsi'lArabî, 1403/1982), 49: 223; Nîşâbûrî de bu tarihi 17 Safer olarak kaydetmektedir. Nîşâbûrî, Takvîm-i Şìa, 67.

49 Ali er-Rızâ'nın zehirlenme olayı hakkında bilgi için bkz. Metin Bozan, "Ali er-Rıza'nın Veliahtlığı Meselesi (İmamiyye'nin İmamet Nazariyesine TeoriPratik Açısından Eleştirel Bir Yaklaşım)", Dinî Araştırmalar 7, sy. 19 (2004): 159-171. 
mekândır. Bu özelliğiyle tarihi süreçte İmam Rızâ ve onun kabri, İran için hem teolojik hem de stratejik bir öneme sahip olagelmiştir. İran açısından ayrı bir öneme sahip olduğu için bu gün İran'da resmi tatildir.

\section{REBÎÜLEVVEL}

8 Rebîülevvel 260- "Şehâdet-i İmam Hasan-1 Askerî (a.s.)"50. Şia'nın on birinci imamı olarak kabul edilen Hasan b. Ali el-Askerî̀nin ölüm yıldönümüdür.

9 Rebîülevvel 260- "Rûz-1 Nasb-1 İmam Mehdi be İmâmet (İmam Mehdi'nin İmamete Atandığ1 Gün)". ${ }^{51}$ Şii itikadına göre on birinci imam'ın vefat ettiği gün on ikinci imamın imamlığa atandığı gün olarak kabul edilmesi gerekirken, bir matem günü olan on birinci imamın şehadeti ile sevinç günü olan on ikinci imamın imamlığa atanma gününün aynı olmaması için bir gün ara ile kutlanmaktadır. Diğer imamların imamlığa atandığ1 günlere özel önem verilmezken on ikinci imamın Şii itikadı açısından taşıdığı önemden dolayı bu gün özel olarak anlamlandırılır. Bu günde güzel kokular sürünmek, sadaka vermek, güzel elbiseler giyinmek, gusül abdesti almak gibi davranışlar teşvik edilmektedir. Kum şehrinin birçok bölgesine asılan afişlerde "Emîru'l-Müminin Ali Aleyhisselam'in Şiileri ve Sevenlerinin Neşesi, Mutluluğu ve Büyük Bayramı" sseklinde ibarelere rastlanmaktadır. Şii literatürde bu güne çeşitli isimlerin de verildiği görülmektedir. Bunlar arasında; Iydullahi'l-Ekber, Gadîr-i Sânî, Iyd-1 Fitr-1 Dovvom, Rûz-1 Ferh-i Şîa, Iyd-1 Ehl-i Beyt a.s, Rûz-i Kabûli-yi A'mâl, Rûz-1

50 Şeyh Müfid takviminde bu tarihi 4 Rebiülevvel olarak vermektedir. Ancak el-İrşad adlı eserinde ve ayrıca Kuleynî 8 Rebiülevvel olarak kaydetmektedir. Büyükkara, Önemli Tarih, Gün ve Geceler, 33; Şeyh Bahâî ise 1 Rebiülevvel olarak kaydetmektedir. Büyükkara, Önemli Tarih, Gün ve Geceler, 54; Şeyh Tûsî de 1 Rebiülevvel olarak kabul etmektedir. Şeyh Tûsî, Misbâhu'l-muteheccid, 2: 791; Seyh Abbas Kummî, Mefâtîhu'l-cinân, 511.

51 Bu günün tazim edilmesi ile ilgili çok kısa da olsa en erken bilgilerin İbn Tâvûs'da geçtiği görülmektedir. İbn Tâvûs, el-îkbâlu'l-a'm'al, 3: 114; Şeyh Abbas Kummî, bugünün Şiiler için büyük bir bayram günü olduğunu vurgulamaktadır. Mefâtìhu'l-cinân, 511. 
Pîrûzi-yi Mazlûm, Rûz-1 Dustî-yi Müminîn, Rûz-i Perhiz ez Kebâir, Rûz-i Nâbûdi-yi Dalâlet ve Gomrâhî, Rûz-1 Şükrgozarîn52 sayılabilir.

12 Rebîülevvel- "Velâdet-i Peygamber (s.a.a.)". Hz. Peygamber'in doğum günü olarak kabul edilen gündür. İran'da Hz. Peygamber'in doğum günü ile ilgili iki farklı gün kabul edilmektedir. Bunlardan ilki Ehl-i Sünnet rivayetine de uygun olarak 12 Rebîülevvel, diğeri ise Şiilerin çoğu tarafından kabul edilen 17 Rebîülevvel'dir. Ancak 12 Rebîulevvel’i önemli Şii âlimlerinden Kuleynî de kabul ettiği için doğum günü etkinlikleri bu gün başlamakta ve bir hafta sürmektedir. 12-17 Rebîülevvel arasını kapsayan ve Şii-Sünni kardeşliği ekseninde birlik ve beraberliğe vurgu yapılan bu günlere özel olarak "Vahdet Haftası" adı verilmektedir. Ülke çapında şehirler baştanbaşa süslenmekte, bayram gibi kutlanmaktadır. Her şehirde Sünni âlimlerin de katıldığı konferanslar düzenlenmekte ise de son yıllarda bu konferansların göstermelik hale geldiğine dair önemli itirazlar dillendirilmektedir.

17 Rebîülevvel- "Velâdet-i Peygamber (s.a.a.)". Şia'nın cumhurunun görüşüne göre $\mathrm{Hz}$. Peygamber'in doğum günü olarak kabul edilir. ${ }^{53} \mathrm{Bu}$ gün aynı zamanda Şia'nın altıncı imamı olarak kabul edilen Cafer b. Muhammed es-Sâdık'ın hicri 83 yılında gerçekleşen doğum günüdür. ${ }^{54}$ Resmi tatildir.

\section{REBîüSSÂNî}

8 Rebîuissânî 232- "Velâdet-i İmam Hasan-1 Askerî (a.s.)"55. İmamiyye'nin on birinci imamı olarak kabul edilen Hasan b. Ali el-Askeri'nin doğum günüdür.

52 Nîşâbûrî, Takvîm-i Şìa, 101.

53 Büyükkara, Önemli Tarih, Gün ve Geceler, 34, 56; Şeyh Tûsî, Misbâhu'l-muteheccid, 2: 791; İbn Tâvûs, el-ïkbâlu'l-a'm'al, 3: 119; Meclisî, Zâdu'l-meâd, 260; Şeyh Abbas Kummî, Mefâtîhu'l-cinân, 511.

54 Şeyh Abbas Kummî, Muntehe'l-â'mâl, 2: 191.

55 Şeyh Müfid’in takviminde 10 Rebiülahir olarak geçer. Büyükkara, Önemli Tarih, Gün ve Geceler 35; Nîşâbûrî, Takvîm-i Şìa, 131; Şeyh Tûsî de 10 Rebiülahir olarak verir. Şeyh Tûsî, Misbâhu'l-muteheccid, 2: 792; Şeyh Abbas Kummî, Mefâtîhu'l-cinân, 512. 
10 Rebîüssânî 201- "Şehâdet-i Hazret-i Fâtıma-i Ma'sûme (s.a.)". Şii imamlarından Musa el-Kâzım'ın kızı ve Ali er-Rızâ'nın kız kardeşi Fatıma'nın Horasan yolculuğu sırasında Kum yakınlarında vefat etmesi münasebetiyle düzenlenen anma programına verilen addır. $\mathrm{Bu}$ gün Kum şehrinin tamamı siyah renge bürünür. İran ve özellikle Kum için özel öneme sahip olmasından dolayı bu gün Fatıma'nın türbesi etrafında çeşitli etkinlikler düzenlenir.

\section{CEMÂZIUÜLEVVEL}

5 Cemâziülevvel 5- "Velâdet-i Hz. Zeynep (s.a.)". Hz. Ali'ni kızı Zeynep’in doğum günüdür. ${ }^{56}$ Zeynep, Şiî matem literatürü ve yaşayan halk üzerinde önemli bir kadın figürdür. İmamlardan sonra ismi en çok anılan şahsiyetler arasındadır. Onun isminin Allah tarafindan bizzat vahiy yoluyla Hz. Peygamber'e iletildiği, isminin levh-i mahfuz'da yazılı olduğu şeklindeki rivayetlerle, onun hakkında $\mathrm{Hz}$. Hatice ve Hz. Fatıma'nın ardından onların özelliklerinden izler taşıyan manevi derecesi yüksek bir profil çizilmektedir. ${ }^{57}$ Onun Kerbelâ olay1 sonrasında Şam'da Yezid'in sarayında söylediği sözler cesaret örneği olarak sürekli dillendirilmekte ve kadınların onu örnek almaları gerektiği vurgulanmaktadır.

13 Cemâziülevvel 11- "Şehâdet-i Fâtıma Zehra (s.a.)". 58 Hz. Fatıma'nın şehit edildiğine inanılan gündür. Bu olayın tarihinin biri $\mathrm{Hz}$. Peygamber'in vefatından 75, diğeri 95 gün sonra olduğuna dair iki rivayet bulunmaktadır. Her iki gün de kabul edilmektedir. ${ }^{59}$ Ancak İran'da asıl olarak 3 Cemâziüssâni tarihi kabul edilmektedir.

56 Hz. Ali'nin Hz. Fatıma'dan olan kızıdır. Ümmü'l-Mesâib ve Ümmü'n-Nevâib künyeleriyle anılır. el-Ömerî, el-Mecdî, 199; İ̉n Funduk, Lubâbu'l-ensâb, 1: 337.

57 Nîşâbûrî, Takvîm-i Şìa, 148.

58 Şeyh Müfid'in takviminde 3 Cemâziülâhir 11 olarak geçmektedir. Büyükkara, Önemli Tarih, Gün ve Geceler, 36; İlk olarak Meclisî bu günde matem merasimi kavramından bahsetmekte ve Fatıma'ya ve bașta Ebubekir ve Ömer olmak üzere onun düşmanlarına lanet edilmesi tavsiyesinde bulunmaktadır. Meclisî, Zâdu'l-meâd, 281; Hz. Fatıma'nın vefat tarihi ile ilgili farklı rivayetler için bkz. Nîşâbûrî, Takvîm-i Şîa, 164-165.

59 Nîşâbûrî, Takvîm-i Şìa, 135. 


\section{CEMÂZIÜSSÂNî}

3 Cemâziüssânî 11 - "Şehâdet-i Fatıma Zehra (s.a.)". Şiiler tarafından "Seyyidetünnisâ" olarak anılan Hz. Fatıma'nın vefat ettiği gündür. ${ }^{60}$ Resmi tatildir. Şii gelenek açısından önemli bir karakter olan Hz. Fatıma'nın vefatı İran'da Aşura'dan sonraki en görkemli anmalara sahne olmaktadır. Hz. Fatıma'nın ne şekilde vefat ettiği Şii ve Sünni kesim arasında yüzyıllardır tartışmalı bir mesele olagelmiştir. İnsanları sürekli matem ortamında tutma amaciyla olsa gerek ilk kabul edilen 13 Cemâziülevvel ile bu gün arasındaki 20 güne "Eyyâm-1 Fâtımiyye" denilmektedir. Yirmi gün boyunca İran'ın dini liderinin önderlik ettiği anma programları yapılmaktadır. Normalde 10 günlük süreleri kapsayan zaman dilimleri için "Dehe" adlı kavram kullanılmakta ise de bu olaya özel bir "dehe" daha kabul edilerek toplam 20 gün matem merasimi yapılmaktadır. Bunlardan birincisi 10-20 Cemâziülevvel tarihleri arasında "Dehe-i Fâtımıyye-yi Evvel", diğeri 1-10 Cemâziüssânî arasında "Dehe-i Fatımıyye-yi Dovvom" şeklinde isimlendirilmiştir. ${ }^{61} \mathrm{Bu}$ on günlük sürelerin her birinde 3 gece boyunca matemin daha görkemli hale getirildiği çeşitli anma törenleri yapilir.

13 Cemâziüssânî- "Rûz-i Tekrîm-i Mâderân ve Hemserân-1 Şühedâ (Anneler ve Şehit Eşlerini Yüceltme Günü)”. Hz. Ali'nin hanımı ve Ebu'l-Fazl'ın annesi Ümmü'l-Benîn'in vefat yıldönümü İran'da özel bir güne dönüştürülmüştür. Yukarıda da geçtiği gibi Ebu'l-Fazl'ın Şiiler açısından önemi böyle bir günün ortaya çıkarılmasında rol oynamıştır. Ancak ilk dönem kaynaklarında böyle bir günden bahsedilmemektedir. 62

20 Cemâziüssânî- "Velâdet-i Hazret-i Zehra (s.a.)",63 "Rûz-1 Zen (Kadınlar Günü)”. Hz. Fatıma'nın doğum günü olarak kabul edilen

60 Şeyh Tûsî, Misbâhu'l-muteheccid, 2: 793.

61 http://www.beytoote.com/art/decorum/start3-decade2-fatemiyeh.html (Erişim: 28 Eylül 2017)

62 Şeyh Tûsî, Misbâhu'l-muteheccid, 2: 793-795.

63 Şeyh Tûsî, Misbâhu'l-muteheccid, 2: 793; İbn Tâvûs, el-İkbâlu'l-a'm'al, 3: 162; Meclisî, Zâdu'l-meâd, 281. 
bu gün, İran'da "Kadınlar günü" olarak kutlanmaktadır. ${ }^{64}$ Resmi tatildir. Batı ülkelerinde kutlanan kadınlar gününün İran'a yansıması olarak devrimden önceki Şah rejimi döneminde hanedandan Feride Kutbî'nin doğum günü olan 25 Azer (16 Aralık) tarihinde kutlanan Kadınlar Günü, devrimden sonra Hz. Fatıma'nın doğum gününe çevrilmiştir. ${ }^{65}$ Onun doğumu onlarca mucize eşliğinde etkili vaizler tarafindan sunulmaktadır. Bu günde eşlerin hanımlarına, çocukların annelerine hediye alması teşvik edilmektedir. Modern dönemde ortaya çıkmış böyle bir günün $\mathrm{Hz}$. Fatıma ile ilişkilendirilerek kutlanması Şiiliğin kendini güncellemeye çalıştığının bir kanıtı olarak görülebilir.

20 Cemâziüssânî 1320/1941 - İran devrimi lideri Ayetullah Humeynî'nin doğum günüdür. Normalde hicri-şemsi takvime göre kutlanması gereken bu gün devrim liderinin dini karakter taşımasından hareketle hicri-kameri takvimde de yer almaktadır.

\section{RECEP}

1 Recep 57- "Velâdet-i İmam Muhammed el-Bâkır (a.s.)"66 Şîa'nın beşinci imam olarak kabul ettiği Muhammed el-Bâkır'ın doğum günüdür.

3 Recep 254- "Şehâdet-i Ali el-Hâdi (a.s.)"67 Şîa'nın onuncu imam olarak kabul ettiği Ali el-Hâdî'nin vefat ettiği gündür.

10 Recep 195- "Velâdet-i İmam Muhammed el-Cevad (a.s.)". Şîa'nın dokuzuncu imam olarak kabul ettiği Muhammed b. Ali elCevâd'ın doğum günüdür. ${ }^{68}$

64 Şeyh Abbas Kummî, Muntehe'l-â'mâl, 1: 213.

65 https://mamasite.ir/fa/news/304374/1395- تاريخهه-روز-زن-و-مادر،-روز-مادر (Erişim: 9 Eylül 2017)

66 Şeyh Müfid takviminde de aynı tarih kabul edilir. Büyükkara, Önemli Tarih, Gün ve Geceler, 37; Nîşâbûrî, Takvîm-i Şîa, 185.

67 Şeyh Müfid takviminde de aynı tarih kabul edilir. Büyükkara, Önemli Tarih, Gün ve Geceler, 37; Nîşâbûrî, Takvîm-i Şìa, 186-187.

68 SSeyh Müfid takviminde Muhammed b. Ali'nin doğum tarihini aynı yılın 15 Ramazan'1 olarak verir. Büyükkara, Önemli Tarih, Gün ve Geceler, 18; Şeyh Abbas Kummî, Mefâtîhu'l-cinân, 260; Nîşâbûrî, Takvîm-i Şìa, 189. 
13 Recep- "Velâdet-i Emîrü'1-Müminin (a.s.)". Ali b. Ebî Tâlib’in doğum günüdür. ${ }^{69}$ İran'da resmi tatil ilan edilmektedir. Aynı zamanda bu güne özel bir anlam verme kapsamında "Rûz-1 Merd (Erkekler/Babalar Günü)" şeklinde adlandırılmakta ve bu günde çocukların babalarına, hanımların eşlerine hediye alması teşvik edilmektedir. Yine modern dönemde birçok ülke tarafindan kabul edilen böyle bir günün mezhebi pratiklere yansıdığını görmekteyiz.

13-14-15 Recep ${ }^{70}$ - "Eyyâm-1 İtikaf" (İtikaf Günleri). İran toplumunun dini hayatında önemli olarak görülen günlerdendir. Halkın dindar kesimi camilere oruç ve ibadet için gitmekte ve bu günlerde camilerde yatılmaktadır. Bunun için devlet ve sivil toplum kuruluşları tarafından özel imkânlar seferber edilip caminin donanımı uygun hale getirilmeye çalışılmaktadır. Bu günlerde özellikle dini kimliği ile bilinen Kum şehrinde halkın camilere rağbetinin yoğun olduğu gözlemlenmiştir.

15 Recep 62- "Vefât-1 Hazret-i Zeynep (s.a.)". ${ }^{71} \mathrm{~Hz}$. Ali'nin kızı Zeynep'in vefat y1ldönümüdür. Doğum gününde olduğu gibi vefat gününde de onun ayırt edici vasıfları sıralanıp özellikle kadınlar için örnek yönleri vurgulanmaktadır.

25 Recep 183- "Şehâdet-i İmam Musa Kâzım (a.s.)". ${ }^{72}$ Şia'nın yedinci imamı olarak kabul edilen Musa b. Cafer el-Kâzım'ın Abbasî Halifesi Harun Reşid'in zindanında vefat ettiği tarihtir. Şia'nın tarihsel olaylara verdiği önemin bir gereği olarak bu günde Ehl-i Beyt'e yapılan zulümler hatırlatılarak insanların zihinleri tarihsel hadiseler yoluyla sürekli canlı tutulur. Harun Reşid'in şahsında Şia'ya zarar

69 Şeyh Bahâî bu tarihi kabul etmekte ancak Şeyh Müfid 23 Recep olarak kaydetmektedir. Büyükkara, Önemli Tarih, Gün ve Geceler, 64; Meclisî, Zâdu'lmeâd, 24; Nîşâbûrî, Takvîm-i Şîa, 195-206.

70 Şeyh Tûsî, 15 Recep günü 12 rekatlık özel bir namaz kılmanın müstehab olduğunu vurgulamaktadır. Şeyh Tûsî, Misbâhu'l-muteheccid, 2: 806; Bu günlerin önemine ilk vurgunun Meclisî ile başladığı düşünülmektedir. Meclisî, Zâdu'l-meâd, 24-25; Şeyh Abbas Kummî, Mefâtîhu'l-cinân, 260-261.

71 Nîşâbûrî, Takvîm-i Şìa, 207.

72 Şeyh Müfid aynı tarihi kabul eder. Büyükkara, Önemli Tarih, Gün ve Geceler, 38; Meclisî, Zâdu'l-meâd, 34; Şeyh Abbas Kummî, Mefâtîhu'l-cinân, 270; Nîşâbûrî, Takvîm-i Şîa, 216. 
vermiş bütün tarihsel karakterler günümüzde yaşayan ve İran düşmanı olan şahıslarla özdeşlik kurularak anlatılır. ${ }^{73}$

27 Recep- "Iyd-1 Meb'as" (Peygamberlik Bayram1). ${ }^{74} \mathrm{~Hz}$. Peygamber'in peygamberlik görevine başladığ gün olarak kabul edilir. İran'da resmi tatildir. Resmi tatil olmasının dışında gözle görülür bir etkinliğin olmadığı, diğer bayramlara nazaran daha sönük geçtiği gözlenmektedir. Bu günün Şii gelenekte eskiden beri kutlandığ1 görülmektedir. Nitekim Şeyh Tûsî, 27 Receb'i "Leyletu'l-Meb'as" olarak zikretmekte, bugüne özel 12 rekatlık bir namaz kılmanın, gusül abdesti almanın ve oruç tutmanın müstehab olduğunu vurgulamaktadır. ${ }^{75}$ İbn Battuta'nın nakline göre ise, "Mahya Gecesi" adı verilen Recep ayının 27. gecesi Hz. Ali'nin kabrinin bulunduğu Necef'teki Şiiler, Irakeyn, Horasan, Fâris ve Anadolu ahalisinden 30, 40 kadar kötürüm getirip yatsıdan sonra onları kabrin üzerine koyarak kalkmalarını beklerler. Kendileri de Ravda'yı (Hz. Ali'nin kabrini) seyreder, namaz kılar, dua ve zikirle meşgul olurlar. ${ }^{76}$ Aynı geceyi Sünniler, Miraç gecesi olarak kutlamaktadirlar.

\section{ŞABAN}

3 Şaban 4- "Velâdet-i İmam Hüseyin (a.s.)"77. Hz. Hüseyin'in doğum günüdür. Bu güne aynı zamanda "Rûz-1 Pâsdâr" (Muhafız günü)

73 Sözgelimi 2013 yılında radyodan dinlediğimiz bir anma programında Harun Reşid'in zulümleriyle ABD Başkanı Obama'nın yaptıkları karşılaştırılmaktaydi.

74 Şeyh Müfid aynı tarihi kabul eder. Büyükkara, Önemli Tarih, Gün ve Geceler, 39; İbn Tâvûs 25 Recep olarak belirtir. İbn Tâvûs, el-ïkbâlu'l-a'm'al, 3: 262; Meclisî, Zâdu'l-meâd, 35; Şeyh Abbas Kummî, Mefâtîhu'l-cinân, 270-275; Nîşâbûrî, Takvîm-i Şîa, 221-223.

75 Şeyh Tûsî, Misbâhu'l-muteheccid, 2: 813-817; Aynı şekilde İbn Tâvûs da bugüne özel çok sayıda nafile ibadetten bahsetmektedir. İbn Tâvûs, el-İkbâlu'la'm'al, 3: 264-276.

76 Ebû Abdullah Muhammed İbn Battuta Tancî, İbn Battuta Seyahatnamesi I, çev. A.Sait Aykut (İstanbul: Yapı Kredi Yayınları, 2004), 252.

77 Büyükkara, Önemli Tarih, Gün ve Geceler, 39; Şeyh Tûsî, Misbâhu'l-muteheccid, 2: 826; İbn Tâvûs, el-i்kbâlu'l-a'm'al, 3: 303; Meclisî, Zâdu'l-meâd, 51; Şeyh Abbas Kummî, Mefâtîhu'l-cinân, 292; Nîşâbûrî, Takvîm-i Şìa, 233. 
adı da verilmektedir. ${ }^{78}$ Onun doğumu ve hayatı mucizeler eşliğinde anlatilır.

4 Şaban 26- "Velâdet-i Hz. Abbas". Hz. Ali'nin oğlu Ebu'l-Fazl Abbas'in doğum günü olarak kabul edilir. Bu gün Ebu'l-Fazl'ın anısına İran'da "Rûz-1 Cânbâz" yani "Gaziler günü" olarak kutlanmaktadır. Ebu'l-Fazl, Şia açısından kendine özgü özel bir konuma sahiptir. Onun lakapları arasında "Kamer-i Munîr-i Benî Haşim" (Haşimoğullarının parlayan ayı), "Bâbu'l-Havâic"79 gibileri bulunmaktadır. Şiilerin cesaret ve kuvvet timsali olarak her türlü ortamda andıkları, ismi etrafında yüzlerce mucizevi olayın cereyan ettiğine inanılan ve "mit" haline getirilmiş bir şahsiyettir. Çoğu zaman onun gerçek kişiliği ile menkabevi kişiliği birbirine karışmaktadır. İran halkının günlük yaşamına o denli nüfuz etmiştir ki güç gerektiren herhangi bir işten önce "Yâ Ebe'l-Fezl" nidası ile hareket edilmektedir. Bu özelliğiyle bir nevi olağanüstü güçlere sahip bir kahraman olarak görülmektedir. Öyle görünmektedir ki, Kerbelâ olayı sırasında Hz. Hüseyin'in sancağını taşıyan alemdarı olması onu matem günlerinin en önemli figürlerinden biri haline getirmiştir. Kerbelâ meydanında verdiği mücadele orada yaşıyormuşçasına duygulu ve coşkulu halde anlatılmaktadır. Önce bir elini sonra diğer elini kaybetmiş, Allah ona cennetteki meleklerle uçması için iki kanat vermiştir. Onun şehitler arasındaki yerinin bütün şüheda arasında müstesna vaziyette olduğu kabul edilmektedir. 80

5 Şaban 38- "Velâdet-i İmam Zeynelabidin (a.s.)". ${ }^{81} \mathrm{~Hz}$. Hüseyin'in oğlu ve Şiiler tarafından dördüncü imam olarak kabul edilen Ali b. Hüseyin Zeyne'l-Âbidin'in doğum günü olarak kutlanmaktadır.

78 http://www.hawzah.net/fa/Magazine/View/3872/6270/68414/ روز-بپاسدار (Erişim: 17 Kasım 2017)

79 İhtiyaçların karşıladığı kapı anlamına gelen bu unvanın, masum olduğuna inanılmayan bir kişi için kullanılması Ebu'l-Fazl'ın İran kültürü açısından ne kadar önemli görüldüğünü göstermektedir. Ebu'l-Fazl'ın bu unvanla anılması daha ziyade Azeri Türkleri arasında yaygındır.

80 Nîşâbûrî, Takvîm-i Şìa, 238.

81 Şeyh Müfid, 15 Cemâziülevvel tarihini kabul etmektedir. Şeyh Bahâî ise bu tarihte muvafıktır. Büyükkara, Önemli Tarih, Gün ve Geceler, 66; Şeyh Tûsî 
11 Şaban 33- "Velâdet-i Hazret-i Ali Ekber (s.a.)". Hz. Hüseyin’in oğlu Ali'nin doğum günü olarak kutlanır. Onun sima olarak Hz. Peygamber'e en çok benzeyen kişi olduğu rivayet edilmektedir. ${ }^{82}$ Aynı zamanda son yıllarda bu güne özel "Rûz-1 Cevân" (Genç Günü) şeklinde bir isimlendirmeye de rastlanmaktadır. ${ }^{83}$

15 Şaban 255- "Nîme-i Şaban (Şaban'ın Ortas1)" olarak meşhurdur. Şia tarafindan on ikinci imam olarak kabul edilen ve gaybette olduğuna inanılan Muhammed el-Mehdi'nin doğum günü olarak kutlanır. İran'da Gadîr-i Hum'dan sonra bayram olarak en görkemli kutlamalara sahne olan gündür. Özellikle Kum'da bulunan ve yapım talimatının bizzat Mehdî tarafından verildiğine inanılan Cemkerân mescidinde büyük bir etkinlik yapılmaktadır. Aynı zamanda bu gün resmi tatildir. Onun doğumunun yeryüzü için bir rahmet olduğu çeşitli mucizelerle anlatılır. Doğduğu gün zemzem suyunun miktarının arttığ1 ve herkes tarafından gözle görülür hale geldiği belirtilir. ${ }^{84}$ Onun doğumu şerefine birçok kişinin cehennem ateşinden kurtulma yazısının yazıldığı bundan dolayı bu geceye "Berat Gecesi" de dendiği söylenir. ${ }^{85}$ Sünnî gelenekte aynı tarihte kutlanan "Berat Kandili"nin Şiî forma dönüştüğü ve yaşatıldığı görülmektedir.

ve İbn Tâvus da 15 Cemâziülevvel olarak kaydetmekte ve bugün oruç tutmanın müstahab olduğunu zikretmektedir. Şeyh Tûsî, Misbâhu'l-muteheccid, 2: 792; İbn Tâvûs, el-ïkbâlu'l-a'm'al, 3: 156.

82 Nîşâbûrî, Takvîm-i Şìa, 240-241.

83 http://setare.com/fa/news/11090/Erişim 17 Kasim 2017)

84 Doğumu etrafında meydana geldiğine inanılan mucizevi olaylar için bkz. Ebû Cafer Muhammed b. el-Hasen Şeyh Tusi (ö. 460/1067), el-Gaybe li'l-hucce (Kum: Dâru'l-Meârifi'l-İslâmî, 1411/1990), 229-252.

85 Nîşâbûrî, Takvîm-i Şîa, 241; Şeyh Tûsî, bu gün ile ilgili Sünni geleneğin alg1siyla da uyumlu olarak günü ihya etme maksatlı namaz, oruç ve dualardan oluşan rivayetleri sıralamakta, Mehdî'nin doğum gününü de en sonda kisaca zikretmektedir. Bu durum, kendi yaşadığı asırda Şii toplumunun bu günü bütün Müslümanlarca da kabul edildiği gibi günahlardan kurtuluşa bir vesile olarak saydıkları görülmektedir. İmam Mehdi'yi de bu vesileyle kısaca andıkları görülmekte iken sonraki asırlarda günün diğer anlamları geri plana atılarak Mehdî ön plana çıkartılmış, gece ile ilgili diğer rivayetler Mehdî algısına paralel olarak yorumlanmıștır. Şeyh Tûsî, Misbâhu'l-muteheccid, 2: 829-844; Ayn1 yaklaşım İbn Tâvûs'da da görülmektedir. İbn Tâvûs, elİkbâlu'l-a'm'al, 3: 312-355; 15 Şaban'1 Mehdi ile ilişkilendiren ilk güçlü vurgunun Meclisî ile başladığı, günümüzde ise en çok okunan kitaplar arasında 


\section{RAMAZAN 86}

10 Ramazan hicretten 3 yıl önce- "Vefât-1 Hazret-i Hatice (s.a.)". Hz. Hatice'nin vefat yıldönümüdür. Hz. Hatice, Hz. Fatıma'nın annesi olarak İmamiyye Şiileri arasında Peygamberimizin diğer eşlerine nazaran daha önemli bir mevkiye sahiptir. 87

15 Ramazan 3- "Velâdet-i İmam Hasen-i Mücteba (a.s.)". Şia'nın ikinci imamı olarak kabul edilen Hz. Hasan'ın doğum günü olarak kutlanmaktadır. 88 "Rûz-1 İkrâm" (İkram/Sayg1 Günü) olarak adland1rılmıştır. ${ }^{89}$

17 Ramazan- "Mi'rac-1 Peygamber". Hz. Peygamber'in miraca yükseldiği gün olarak kabul edilir. Şii itikadına göre Hz. Peygamber miraca bedenen ve uyanık haldeyken yükselmiştir. Sünni gelenek tarafından da dillendirilen ve miraçta çeşitli peygamberlerle yapılan görüşmeler Şii geleneğe de aynı şekilde yansımıştır. ${ }^{90}$

19 Ramazan 40- "Rûz-i Zerbet (Darbe Günü)" Hz. Ali'nin vefatına yol açan kılıç darbesini aldığı gün olarak kabul edilmektedir. ${ }^{91}$

18-20-22 Ramazan- Bu günlerin gecesi Kadir Gecesi olarak kabul edilip kutlanmaktadır. Özel bir adlandırmayla "Şeb-i İhyâ" (İhya gecesi) olarak anılmaktadır. ${ }^{92}$

yer alan Mefâtîhu'l-cinân ile devam ettiği görülmektedir. Meclisî, Zâdu'lmeâd, 55-56; Şeyh Abbas Kummî, Mefâtîhu'l-cinân, 295.

86 Şeyh Tûsî, uzun bir bölüm ayırdığı Ramazan ayında namaz, oruç ve nafileler, itikaf günleri ve bu günlerde okunacak dualara geniş yer verirken özel anlamı olan başka hiçbir günden bahsetmemektedir. Şeyh Tûsî, Misbâhu'lmuteheccid, 2; 539-648.

87 Şeyh Müfid'in takviminde de bu tarih geçer. İbn Sa'd da bu tarihle muvafiktır. Büyükkara, Önemli Tarih, Gün ve Geceler, 17 (7 no'lu dipnot).

88 Nîşâbûrî, Takvîm-i Şìa, 276.

89 http://www.ettelaat.com/etiran/?p=131258 (Erişim: 17 Kasım 2017)

90 Nîşâbûrî, Takvîm-i Şîa, 278-79.

91 Şeyh Müfid takviminde de aynı tarih kabul edilir. İbn Sa'd ve Taberi de bu tarihle muvafiktır. (Bkz. Büyükkara, Önemli Tarih, Gün ve Geceler, 18; Nîşâbûrî, Takvîm-i Şîa, 286.

92 Şeyh Müfid takviminde 23 Ramazan'ın Kadir gecesi olmasının umulduğunu belirtmektedir. Büyükkara, Önemli Tarih, Gün ve Geceler, 19; Meclisî, Zâdu'lmeâd, 122-128; Şeyh Abbas Kummî, Mefâtîhu'l-cinân, 398. 
21 Ramazan 40- "Şehâdet-i İmam Ali (a.s.)". Hz. Ali'nin şehit edildiği gündür. Resmi tatil günüdür. ${ }^{93}$

Ramazan ayının son Cuma günü- "Rûz-i Cihânî-yi Kuds" (Dünya Kudüs Günü). Dünya Müslümanları tarafindan dini bir dava olarak görülen Filistin sorunu İran halkı tarafından da aynı coşkuyla kabul edilmektedir. İsrail ile İran arasındaki siyasi gerilimin de canlı tutulmaya gayret gösterildiği bu günde, İran genelinde toplu gösteriler yoluyla Filistin davasına destek verilir ve İsrail lanetlenir. Gösterilerin merkezi Tahran şehridir. Burada Cuma imamının ve devlet büyüklerinin katılımıyla uzun bir yürüyüş yapılarak halkın katılımı sağlanır.

\section{ŞEVVAL}

1 Şevval- "Iyd-1 Saîd-i F1tr". Ramazan Bayramı. Ülkemizdekinin aksine Ramazan Bayramı 2 gün olarak kabul edilmektedir. Resmi tatil'dir. ${ }^{94}$ Bayram namazından önce $\mathrm{Hz}$. Hüseyin'in toprağından teberrüken bir miktar yemek müstehap kabul edilmektedir. ${ }^{95}$

25 Şevval 148- "Şehâdet-i İmam Cafer Sadık (a.s.)". ${ }^{96}$ Resmi tatildir. Hz. Ali dışındaki diğer imamlara nazaran Cafer-i Sadık'ın vefatının resmi tatil olarak kabul edilmesi, Şii düşüncenin gelişiminde ona verilen değerle ilgilidir.

\section{ZİLKADE}

1 Zilkade 173- "Velâdet-i Hz. Masume (s.a.)". Musa el-Kâzım'in kızı Fatıma Ma'sume'nin doğum günü olarak kabul edilmektedir. "Rûz-1 Dohter (Kızlar Günü)" olarak kutlanır. Özellikle Kum şehri hiç olmadığı kadar renkli gösterilere sahne olmaktadır. Yılın diğer zamanlarında giyimden süslemelere kadar siyah rengin hâkim olduğu şehrin sokakları renkli afiş ve flamalarla süslenmektedir.

93 Şeyh Müfid ve Şeyh Bahâî'nin takviminde aynı tarih kabul edilir. Kuleyni 9 Ramazan olarak verir. Taberî ise 17 ve 19 Ramazanla birlikte Rebiülahir ayını da vermektedir. Büyükkara, Önemli Tarih, Gün ve Geceler, 19, 69.

94 Şeyh Müfid bugünün Amr b. As'nn helak olduğu gün olması itibariyle de önemli olduğunu vurgular. Büyükkara, Önemli Tarih, Gün ve Geceler, 19.

95 Nîşâbûrî, Takvîm-i Şìa, 301.

96 Şeyh Abbas Kummî, Mefâtîhu'l-cinân, 433; Nîşâbûrî, Takvîm-i Şìa, 320. 
5 Zilkade- "Rûz-1 Teclîl-i İmamzâdegân ve Bekâ-1 Müteberrika" (İmamzadeler ve Onların Türbelerini Yüceltme Günü). İran'ın dini ve kültürel hayatında oldukça önemli bir konuma sahip olan İmamzadeler ve onların türbelerinin önemine vurgu yapıldığı bir gündür. Günümüzde İmamzadelerin Vehhabilere karşı "yumuşak savaş" unsuru olarak görüldüğü belirtilerek İran genelindeki yüzlerce İmamzade türbesinin halk nazarındaki itibarının artırılması için çalışmalar yap1lmaktadir. ${ }^{97}$

11 Zilkade 148- "Velâdet-i İmam Rıza (a.s.)"98. Şìa'nın sekizinci imamı olarak kabul edilen Ali er-Rızâ'nın doğum günü olarak kutlanmaktadir.

1-11 Zilkade- "Dehe-i Kerâmet" günleri. Fatıma Ma'sume'nin doğum günüyle başlayıp ağabeyi Ali er-Rıza'nın doğum günüyle sona eren on güne "Dehe-i Kerâmet" adı verilmektedir. Fatıma'nın Kum'da, Ali er-Rıza'nın Meşhed'de bulunan türbesi İran Şiiliği açısından bu iki şahsın daha fazla ön plana çıkarılmasına vesile olmuştur. İran, hem ülke içindeki hem dünyanın çeşitli bölgelerindeki Şiileri bu iki önemli şahıs etrafında konsolide etmek üzere özel stratejiler geliştirmiştir. Dehe-i Kerâmet adı altında on güne yayılan bu etkinliklerle amaç bu şahısları yüceltip, onlarla ilgili sayısız menkıbeleri zihinlerde sürekli canlı tutarak İran Şiiliğini canlı tutmaktır. Aynı zamanda İran'ın tüm Şiiler için merkezi bir öneme sahip olduğu da teşvik edilmektedir.

30 Zilkade 220- "Şehâdet-i İmam Cevad (a.s.)". Şia'nın dokuzuncu imamı olarak kabul edilen Muhammed b. Ali el-Cevâd'in ölüm y1ldönümüdür. 99

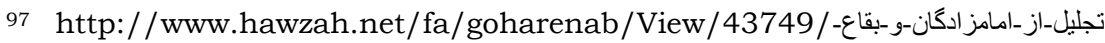
متبركهينجم-ذى_القعده

98 Şeyh Abbas Kummî, Mefâtîhu'l-cinân, 434; Nîşâbûrî, Takvîm-i Şìa, 329.

99 Şeyh Abbas Kummî, Mefâtîhu'l-cinân, 438; Nîşâbûrî, Takvîm-i Şìa, 335.
} 


\section{ZİLHİCCE}

1 Zilhicce 2- Hz. Ali ile Hz. Fatıma'nın evlilik yıldönümü olarak kabul edilmektedir. 1002013 y1lından itibaren bu günü daha da anlamlı kılmak adına "Aile ve Evlilik Haftası" adı altında bir dizi etkinliğe yer verilmektedir. Bu güne bir saygı ifadesi olarak boşanma kaydı resmi kütük defterine işlenmemektedir. Boşanma işlemi kesinleşenlerin kaydı bir gün sonra gerçekleştirilmektedir. ${ }^{101}$ Şiiliğin gündelik hayatın ne kadar içinde olduğunu göstermesi bakımından dikkate değer bir uygulamadır.

6 Zilhicce 1407- "Rûz-i Hunîn-i Hacc". Hacıların Suud ailesi tarafından öldürülmesi günü. İlginç bir şekilde genellikle son dönem olaylarını Şemsi takvime göre veren İranlılar, muhtemelen olayın daha çok dini boyutunu gündeme getirmek ve Hac olayıyla daha fazla irtibat kurabilmek adına Hicri takvimi esas almışlardır. İran'ın sorun yaşadığı ülkelerden birisi olan Suudi Arabistan'ın halk nazarında kötülenmesi adına bütün propaganda araçlarının kullanıldığı bir gündür.

7 Zilhicce 114- "Şehâdet-i İmam Muhammed Bâkır (a.s.)". 102 Şia'nın beşinci imamı olarak kabul edilen Muhammed el-Bâkır'ın ölüm y1ldönümüdür.

9 Zilhicce 61- "Rûz-i Niyâyiş". ${ }^{103}$ Kurban bayramının Arefe gününün İran'daki özel ismidir. Arefe duası etkinliklerinin yapıldığı gündür. Hz. Hüseyin'in Hac'da iken Arefe gününde okuduğu dualar İran

100 Şeyh Müfid de aynı tarihi kabul etmektedir. Büyükkara, Önemli Tarih, Gün ve Geceler, 21; Şeyh Tûsî, aynı tarihi kabul etmekte ancak bazı rivayetlere göre Zilhicce'nin altısı olarak da kabul edildiğini belirmektedir. Ayrıca bugün "Fâtıma Namazı" adında dört rekatlık, içinde çeşitli tesbihatların yapıldığı bir namazı kılmanın müstehab olduğunu vurgulamaktadır. Şeyh Tûsî, Misbâhu'l-muteheccid, 2: 671); Meclisî, Zâdu'l-meâd, 162; Nîşâbûrî 6 Zilhicce olarak vermektedir. Ancak İran'da 1 Zilhicce tarihi esas alınmaktadır. Nîşâbûrî, Takvîm-i Şîa, 346-356.

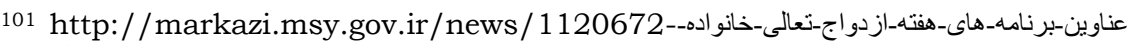

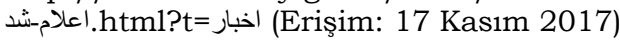

102 Şeyh Abbas Kummî, Mefâtîhu'l-cinân, 442; Nîşâbûrî, Takvîm-i Şìa, 357.

103 Ne Şeyh Müfid ne de Şeyh Bahâî takviminde bugünün Hz. Hüseyin'le herhangi bir irtibatından bahsetmektedir. Şeyh Müfid'in bugüne dair kaydettiği olaylar arasında Hz. Adem'in Allah tarafından affedilmesi, Hz. İbrahim'in do- 
genelinde okunmaktadır. Şii kaynaklarında Arefe gününde Hz. Hüseyin'in kabrini ziyaret etmenin bin hac, bin umre ve Rasulullah'la beraber bin gazve sevabına ulaşacağını belirten rivayetlerin yanında, ${ }^{104}$ eğer kişi Ramazan ayı boyunca bağışlanmamışsa Kurban Bayramının Arefe günü gölgesi olmayan bir yerde güneş altında dua ederse bağışlanacağını belirten rivayetlere de rastlanmaktadır. ${ }^{105}$ Ancak sürekli olarak dillendirilmesine rağmen bu rivayetin halk nazarında pek etkili olduğu söylenemez. Nitekim yapılan gözlemlerde halkın daha ziyade gölgeli yerde dua ettikleri görülmüştür.

Aynı gün "Şehâdet-i Müslim b. Akil"' olarak da anılmaktadır. Hz. Hüseyin’in Kûfe'ye yolladığı elçisi ve amcasının oğlu Müslim b. Akil’in Emevi askerlerince öldürüldüğü gün olarak kabul edilmektedir. ${ }^{106}$

10 Zilhicce- "Iyd-1 Saîd-i Kurban" Kurban Bayram1. İki gün tatil olmaktadır. İran'da Kurban bayramı diğer bayramlara nazaran daha sönük geçmektedir. Türkiye'de görmeye alış1k olduğumuz manzaralara rastlanmamakta, kurban kesenlerin ülkemize göre daha az olduğu gözlemlenmektedir. Ancak özellikle son birkaç yılda bu oranın arttığı söylenmektedir.

Son y1llarda 10-18 Zilhicce'yi kapsayan zaman dilimine "Dehe-i İmâmet ve Velâyet" adı verilmeye başlanmıştır. Bu günlerde bizzat dini liderin talimatı ve gözetiminde imamet, velayet, Gadir günü, velayet-i fakîh'in önemi ile ilgili tebliğ faaliyetleri yanında sosyal ve kültürel etkinliklerle halk Gadir-i Hum bayramına hazırlanmakta, zihinler canlı tutulmaktadır. ${ }^{107}$

ğum günü, Hz. Davud'un tevbesinin kabul edildiği gün, İsa b. Meryem’in doğum günü ve Müslim b. Akil’in şehit edildiği gün olarak kayıt düşmektedir. Büyükkara, Önemli Tarih, Gün ve Geceler, 22.

104 Cafer b. Muhammed el-Kummî İbn Kûleveyh (ö. 368/978), Kâmilu'z-ziyârât, thk. Cevâd el-Kayyûmî (Kum: Neşru'l-Fukaha, 1429/2009), 169-173.

105 Şeyh Tûsî, Misbâhu'l-muteheccid, 2: 714-717; Meclisî, Zâdu'l-meâd, 170-172.

106 Nîşâbûrî, Takvîm-i Şìa, 361.

107 http: / / www.598.ir/fa/news / شعار -دهل_امامت-و-و لايت_مشخص-شد / 173632 (Erişim 28 Eylül 2017) 
15 Zilhicce 212- "Velâdet-i İmam Hâdî (a.s.)". Şia'nın onuncu imamı olarak kabul edilen Ali en-Hâdî’nin doğum günüdür. 108

18 Zilhicce 10- "Iyd-1 Saîd-i Gadîr-i Hum" (Gadîr-i Hum Bayram1). ${ }^{109}$ İan'ın en görkemli bayramlarından birisidir. Âl-i Muhammed'in en büyük bayramı olarak kabul edilir. Resmi tatildir. Yıl boyu matem havasının hâkim olduğu İran sokaklarında halkın gözlerinin içinin güldüğü nadir günlerden birisidir. Bayramdan önce İran'ın dini lideri Ayetullah Ali Hamaneî tarafından bu güne özel geleneksel hale getirilmiş olan mahkumların affedilme haberi yayılmaktadır. Özellikle devlete karşı işlenmiş suçlardan hüküm giyenlerle küçük suçlardan hüküm giyenlerin cezaları affedilmektedir. Örneğin bu bağlamda bizim de bulunduğumuz 2013 y1lında 1241 mahkumun affedildiği duyurulmuştur.

24 Zilhicce 9 - "Rûz-1 Mübâhele" (Mübâhele Günü). ${ }^{110}$ İslam Tarihinde "Mübâhele" olarak bilinen Hz. Peygamber'in Necran Hristiyanlarını temsilen Medine'ye gelen heyetle yaşadığı lanetleşme olayının yıldönümüdür. ${ }^{111}$ Söz konusu olay, Ehl-i Beyt'in kimlerden oluş-

108 Şeyh Müfid'in takviminde 27 Zilhicce olarak yer almaktadır. Ancak Şeyh Müfid'in diğer eseri el-İrşad'da, Kuleyni'de ve Şeyh Bahâî'nin takviminde 15 Zilhicce yer almaktadır. Büyükkara, Önemli Tarih, Gün ve Geceler, 28, 76.

109 Kaynakların üzerinde ittifak ettiği tarihlerdendir. Şeyh Müfid buna ilave olarak bu günü, $\mathrm{Hz}$. Osman'ın katledilmesi ve $\mathrm{Hz}$. Ali'ye biat edildiği gün olarak da kabul etmektedir. Büyükkara, Önemli Tarih, Gün ve Geceler, 25; İbn Tâvûs, bugüne özel 12 rekatlık bir namaz kılmanın müstehab olduğunu belirtmektedir. İbn Tâvûs, el-ỉkbâlu'l-a'm'al, 2: 237; Şeyh Abbas Kummî, Mefâtîhu'l-cinân, 482.

110 Şeyh Müfid de aynı tarihi vermektedir. Büyükkara, Önemli Tarih, Gün ve Geceler, 27; Şeyh Tûsî, 25 Zilhicce olarak vermekte ancak 24 Zilhicce'yi de kabul etmektedir. Şeyh Tûsî'nin daha çok siyasi bir hadise etrafında gelişen böyle bir olayı ve bugüne özel bir dua metnini zikretmesi, Şii geleneğin din ve siyaset konusunda ne kadar iç içe geçtiğini göstermesi açısından önemli bir önektir. Onun başlattığ bu gelenek kendisinden sonra da devam ettirilmiștir. Șeyh Tûsî, Misbâhu'l-muteheccid, 2: 759-760; İbn Tâvûs, el-íkbâlu'la'm'al, 2: 354-368; Meclisî, Zâdu'l-meâd, 218-227; Şeyh Abbas Kummî, Mefâtîhu'l-cinân, 496; Nîşâbûrî, Takvîm-i Şìa, 388.

111 Necran Hristiyanlarından bir heyet, Hz. Peygamber'in onları İslam'a daveti üzerine kendilerinin çok önceden beri Müslüman olduğunu, Hz. İsa'nın babasız doğduğu Kur'an tarafından bildirildiğine göre onun ilah olması gerekeceğini iddia ettiler. Bunun üzerine Hz. Peygamber onları, bir araya gelip 
tuğuna yönelik tartışmalarda Hz. Peygamber'in uygulamasını ve fazilet sıralamasının nasıl olduğuna bir delil sayılarak imametin delillerinden biri sayılmaktadır. Bu nedenle İran'da özel bir önem verilerek bayram havasında kutlanmakta, ${ }^{112}$ bu olayın Şii düşüncenin Kur'an'la tescillendiği ve rakiplerine üstünlük sağlamada özel bir yere sahip olduğu sürekli vurgulanmaktadır. Kürsülerden bu ayet karş1sında Sünnilerin diyecek bir lafının olamayacağı, karşılıklı tartışmalarda bu ayetin muhatabın suratına adeta çarpılması gerektiği küçümseyici bir üslupla dillendirilmektedir.

\section{SONUÇ}

Tarih boyunca ortaya çıkmış bütün dinler/dini hareketlerin inananları arasında birlik ve beraberliği güçlendirmek, onları ortak duygu ve düşünceler etrafında bir araya getirmek üzere çeşitli ritüellere sahip oldukları bilinmektedir. Bu ritüeller aracılığıly bir yandan mensubu bulunulan din/mezhebe aidiyet duyguları güçlendirilmekte, diğer yandan tarihsel süreçte bu yönde elde edilmiş birikimin sonraki nesillere aktarılması amaçlanmaktadır. Bir din ya da inanç sistemi bireye ve topluma ne kadar nüfuz edebiliyorsa onun sonraki kuşaklarca benimsenmesi ve yaşatılması o ölçüde mümkün olmaktadır. Dinlerin ya da inanç sistemlerinin bunu gerçekleştirmede en çok "kutsal zaman"lara yapılan vurguları kullandığı bilinmektedir. Tarih boyunca bazı zamanlar bazı dinler için kutsal kabul edilmiş,

hangi taraf yalancı ve iftiracı ise Allah'ın o tarafa lanet etmesi için dua etmeye çağırdı. Hz. Peygamber belirlenen günde Ali b. Ebî Talib, Hasan, Hüseyin ve Fatıma ile birlikte Necran Hristiyanları ile mübâhele yapmaya gitti. Ancak onlar buna yanaşmayarak cizye ödemeyi kabul ettiler. Mübâhele ayeti olarak da bilinen Âl-i İmran suresinin 61. ayeti bu olay üzerine nazil olmuştur. Şii kaynaklar bu olayda Hz. Peygamber’in yanında götürdüğü şahısların öneminden dolayı olaya daha farklı bir önem atfetmişlerdir. Buna göre Rasulullah, ayette geçen ebnâenâ (çocuklarımızı) lafzına binaen $\mathrm{Hz}$. Hasan ve Hüseyin'i, nisâenâ (kadınlarımızı) lafzına binâen Hz. Fâtıma'yı, enfusenâ (kendimizi) lafzına binaen de $\mathrm{Hz}$. Ali'yi mübâhele mevkine götürmüştü. Olayla ilgili ayrıntılı bilgi için bkz. Mustafa Fayda, "Mübâhele", Türkiye Diyanet Vakfı İslam Ansiklopedisi, 31 (İstanbul: TDV Yayınları, 2006), 425; Büyükkara, Önemli Tarih, Gün ve Geceler, 27 (50 nolu dipnot).

112 İbn Tâvus, bu güne gusül ile başlanıp, oruç tutulmasını, güzel elbiseler giyilmesini ve mümkünse velilerden birinin mezarının ziyaret edilmesini tavsiye etmektedir. İbn Tâvûs, el-ïkbâlu'l-a'm'al, 2: 354. 
bu zamanlarda yapılan ritüellere ayrı bir önem verilerek aidiyet duygularının güçlendirilmesi amaçlanmıştır. İslam dininde de Ramazan, Kurban, Kadir gecesi gibi birçok zaman diliminin özel önemi olduğu hem Kur'an hem de Hz. Peygamber tarafından sürekli vurgulanmıştir.

İslam Mezhepleri arasında kutsal zaman vurgusunu en çok Şiiliğin İmamiyye kolunda gözlemlemekteyiz. Şiilik, y1l içerisinde birçok zaman dilimini diğerlerinden ayırt ederek mensupları arasında mezhebî pratiklerini yüzyıllar boyu sürdürebilmiştir. Bu pratikler arac1lığıla tarihi süreçte mezhep ve ritüeller sürekli güncellenerek günümüze kadar varlığını devam ettirmişlerdir. Bu bağlamda Şiiliğin halen güçlü bir şekilde yaşaması, topluma nüfuz etme kanallarını etkili bir şekilde kullanmasından ileri gelmektedir. Kanaatimizce Şiiliği diger mezheplerden ayırt eden en önemli yanının birey ve toplum muhayyilesine daha fazla vurgu yaparak canlılı̆̆ını muhafaza etme çabasidir.

Şii geleneğin kutsal gün ve gecelere verdiği önemi ilk asırlardan itibaren oluşturulan yoğun dua literatüründe izlememiz mümkündür. Dua literatürünün belli başlı eserleri incelendiğinde erken dönem müelliflerinin gün ve geceler hususunda Müslüman toplumunun geneliyle daha uyumlu olduğu, Recep, Şaban, Ramazan, Muharrem gibi ortak olarak kabul edilen ayların ibadet boyutlarının ön plana çıkarıldığı görülmektedir. İlk dönem müelliflerinin yıl içerisinde çok sayıda gün ve geceyi zikrederek, dini duygu ve düşüncelerin yoğun yaşandığı bu gecelere özel namaz, oruç, sadaka gibi nafile ibadetlere vurgu yaptıkları görülmektedir. Erken dönemde gün ve geceler ve bu zamanlara has ibadetler hakkında müstakil eserler kaleme alan Şeyh Tûsî ve İbn Tâvûs gibi müelliflerin eserleri incelendiğinde birkaç istisna dişında herkesin üzerinde ittifak ettiği hususlara vurgu yaptıkları görülmektedir.

Şiiliğin kutsal zaman algısında tarihi süreç içerisinde farklılıkların oluşmaya başladığı görülmüştür. Başlangiçta diğer mezheplerden sadece Gadir-i Hum, Aşura ve Mübahele gününe yapılan vurgular özelinde farklılaşırken, Şiiliğin devlet kontrolüne girdiği sonraki asırlarda mezhep açısından önemli sayılan gün ve gecelerin artırıldığı an- 
laşılmaktadır. Örneğin Şiiliğin teşekkül sürecinde yaşayan Şeyh Müfid'in takvimiyle, Safevi döneminin ünlü siması Şeyh Bahâînin takvimleri arasında birçok farklılık bulunduğu görülmektedir. Diğer yandan İran devrimiyle birlikte geçmişten beri kültürde yer alan $\mathrm{Hz}$. Ali, Hz. Fatıma gibi mezhep büyüklerinin Anneler Günü, Babalar Günü, Saygı Günü vb isimlerle modern döneme adapte edilmesiyle de mezhebin yenilenmeye ve yeni bir kalıba bürünmeye başladığ $1 \mathrm{da}$ görülmektedir. Bunun yanı sıra modern dönemde Humeyni'nin ölüm yıldönümü, Rûz-i Hunîn-i Hacc, Dehe-i İmâmet ve Velâyet gibi isimlerle gün ihdasının artırılmaya devam ettiği görülmektedir. Öyle ki yıl boyunca İran'da gerek dini gerek milli açıdan önemli sayılmayan gün sayısı neredeyse yok gibidir. Son yıllarda her bir güne kendi öneminin dışında yeni isimler verilerek etki gücü artırılmak istenmektedir. Bu durum mezheplerin tarihi süreç içerisinde kendisini yenilediğini ve yenilendiği oranda topluma nüfuz edebildiğini göstermesi açısından dikkate değerdir.

Şiiliğin gün ve gece anmalarında önemli hususlardan birisi de kadın şahsiyetlere yapılan özel vurgulardır. Hz. Hatice, Hz. Fatıma, Fatıma Ma'sume, Zeynep bnt. Ali, Rukayye bnt. Hüseyin, Ümmü'lBenîn gibi şahsiyetler üzerinden kadınların mezhep açısından taş1dığ1 değer sürekli vurgulanarak onları mezhebin duygusal taşıyıcıları olmak bakımından onore ettikleri görülmüştür. Kadınların bu günlerde özel görevler üstlenmeleri ve aktif olarak katılımları gözlendiğinde istenilen amaca ulaşıldığ anlaş1lmıştır.

İran için önem arz eden Ali er-Rıza ve kız kardeşi Fatıma'nın doğum ve ölüm yıldönümlerine özel önem verilmesi, hem İran Şiiliğini diğer ülkeler nazarında ön plana çıkararak merkezi bir konuma yükseltme çabasını hem de İranlılık bilincini güçlendirme isteğinin sonucu olduğu düşünülmektedir. Diğer yandan Rûz-i Hunîn-i Hacc gibi yeni günler ihdas edilerek İran'ın sorun yaşadığı ülkelerle olan mücadelesi dini alana çekilmek istenmiştir. Böylece din ve siyasetin İran toplumunda nasıl iç içe geçtiği daha rahat anlaşılmaktadır.

Burada dikkat çeken bir diğer husus da imamların ve mezhebin büyüklerinin doğum yıldönümlerine nazaran ölüm yıldönümlerinin ön plana çıkarılmasıdır. Bu durum Safeviler ile birlikte mezhebin ma- 
tem yönünün güçlendirilmeye çalışılmasıyla doğrudan alakalıdır. Safeviler ile birlikte Şiiliğin iktidar gücünü arkasına almasından sonra gün ve gecelerin sayısının artırıldığı, toplumu bir arada tutmaya yönelik törensel yönünün daha fazla ön plana çıkarıldığı anlaşılmaktadır. Safeviler'in başlattığı bu gelenek devam ettirilerek, günümüzde söz konusu gün ve gecelerin törensel ve duygusal boyutlarının daha fazla ön plana çıkarıldığ hatta bazı yıldönümlerinin bir iki haftaya kadar uzatıldığ gözlenmektedir. Sünni geleneğin Mevlit kandili gibi doğum günlerine verdiği önemin aksine Şii gelenek, bazı istisnalarıyla birlikte ölüm tarihlerini ön plana çıkararak yıl boyu matem havasının solunmasını istemiştir. Bu durum, Şiiliğin hem taraftarları hem de diğer mezhepler tarafindan bir matem mezhebi olarak alg1lanmasını haklı çıkarmaktadır.

\section{KAYNAKÇA}

Âmulî, Muhammed b. Hasan Şeyh Hurr (ö. 1104/1692). Vesâilu'şŞîa. thk. Müessesetü Âli'l-Beyt Aleyhisselam. Kum: $1409 / 1988$.

Bozan, Metin. "Şii-İmami Kaynaklarda Kerbelâ'nın Menkâbevi Anlatımı", Çeşitli Yönleriyle Kerbelâ (Tarih Bilimleri I) (Sivas: 2010): 477-492.

Bozan, Metin. “Ali er-Rıza'nın Veliahtlı̆̆1 Meselesi (İmamiyye'nin İmamet Nazariyesine Teori-Pratik Açısından Eleştirel Bir Yaklaşım)", Dinî Araştırmalar 7, sy. 19 (2004): 159-171.

el-Buhârî, Ebû Nasr Sehl b. Abdullah (ö. 4./10. asır). Strru's-Silsileti'l-Aleviyye fì Ensâbi's-Sâdâti'l-Aleviyye. thk. Seyyid Mehdî Recâî. Kum: 1389/2011.

Büyükkara, Mehmet Ali. İmâmiyye Şîasina Göre Önemli Tarih, Gün ve Geceler (Şeyh Müfid ve Şeyh Bahâînin Takvimleri). Çanakkale: 1999.

Büyükkara, Mehmet Ali. "Kerbelâ'dan İnkılaba: İmami-Şii Şehadet Düşüncesi ve Problemleri”. Ankara Üniversitesi Ilahiyat Fakültesi Dergisi XLIII, sy. 2 (2002): 211-247.

Büyükkara, Mehmet Ali. "Çağdaş Şîa Düşüncesinde Kerbelâ'nın Problemli Mirası: İmam Hüseyin Kazanmak İçin mi Yoksa 
Canını Feda İçin mi Ayaklandı?”. Çeşitli Yönleriyle Kerbelâ (Tarih Bilimleri I) (Sivas: 2010): 383-408.

Caferiyan, Resul. "Şîa'da Dua Edebiyatı". çev. Habip Demir. Iğdır Üniversitesi Ilahiyat Fakültesi Dergisi. sy. 6 (Ekim 2015): 209237.

Eliade, Mircea. Kutsal ve Dindışı. çev. Mehmet Ali Kılıçbay. Ankara: Gece Yayınları, 1991.

Fayda, Mustafa. "Mübâhele". Türkiye Diyanet Vakfi İslam Ansiklopedisi. 31:425. İstanbul: TDV Yayınlar1, 2006.

Güner, Ahmet. "Büveyhiler Döneminde Bağdat'ta Kerbelâ/Aşure, Gadir Humm ve Benzeri Şii Uygulamaları". Çeşitli Yönleriyle Kerbelâ (Tarih Bilimleri I) (Sivas: 2010): 325-340.

Güner, Ahmet. "Büveyhiler Dönemi ve Çok Seslilik", Dokuz Eylül Üniversitesi İlahiyat Fakültesi Dergisi 12, (1999): 47-72.

http://www.hawzah.net/fa/occation/view/48956/شهادت_حضرت ابو الفضل_العباس_عليه_السلام

http://www.hawzah.net/fa/Magazine/View/3872/6270/68414/ روز-ياسدار

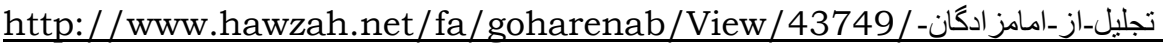
و-بقاع_منبركهينج-ذيـ-القعده

http://www.beytoote.com/art/decorum/start3-decade2-fatemiyeh.html

https://mamasite.ir/fa/news/304374/1395--ماريخجه-روز-زن-و-مادر،-روز مادر

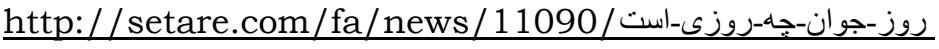

http://www.ettelaat.com/etiran/?p=131258

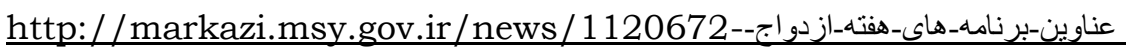
اخبار = تعالى_خانو ادهـاعلام-شد.html?t

http://www.598.ir/fa/news/173632/شعار -دههـامامت-و-و لايت_مشخص-شد

İbn Battuta, Ebû Abdullah Muhammed Tancî. İbn Battuta Seyahatnamesi I. çev. A. Sait Aykut. İstanbul: Yapı Kredi Yayınları, 2004.

İbn Funduk, Ebû'l-Hasen Ali b. Ebî'l-Kâsım b. Zeyd (ö. 565/1169). Lubâbu'l-ensâb ve'l-elkâb ve'l-a'kâb. thk. Seyyid Mehdi 
er-Recâî. Kum: Mektebetu Ayetullah Mar'aşî Necefî, $1385 / 2007$.

İbn Kûleveyh, Cafer b. Muhammed el-Kummî (ö. 368/978). Kâmilu'z-ziyârât, thk. Cevâd el-Kayyûmî. Kum: Neşru'1Fukaha, 1429/2009.

İbn Tâvûs, Ali b. Musa (ö. 664/1266). el-İkbalu bi'l-a'mali'-hasene fìmâ ya'melu merraten fi's-sene. thk. Cevad Kayyûmî İsfehânî. Kum: Mektebu'l-A'lâmi'l-İslâmî, 1414/1993.

el-İrbilî, Ali b. İsa b. Ebi'l-Feth (ö. 693/1293). Keşfu'l-gumme fi ma'rifeti'l-eimme. Beyrut: Dâru'l-Edvâ, 1405/1985.

el-İsfahânî, Ali b. el-Hüseyin Ebu'l Ferec (ö. 356/966). Mekâtilu't-talibiyyîn. Beyrut: Dâru'l-Murtazâ, 1430/2009.

Kandemir, M. Yaşar. "Câbir b. Abdullah". 6: 530-532. Türkiye Diyanet Vakfi İslam Ansiklopedisi. İstanbul: TDV Yayınları, 1992.

el-Kuleynî, Ebû Cafer Muhammed b. Yâkub (ö. 328/939). Usûlu'lkâfì. thk. Ali Ekber el-Gaffârî. Tehran: Dâru'1-Kütübi'lİslâmiyye, 1407/1986.

Kummî, Mesud Nârî. "Olgûhâ-yi Kâlbedi-yi Hüseyniyehâ: Rîşehâ ve Tehavvulât”, Hüner ve Mimarî. 9 (1395/2016): 25-46.

Kummi, Şeyh Abbas. Mefâtîhu'l-cinân, Kum: Âyin-i Dâniş, $1386 / 2007$.

Kummi, SSeyh Abbas. Muntehe'l-âmâl. tsh. Musevî Damegânî. Tehran: İntişârât-1 Peyâm-1 Âzâdî, 1390/2011.

Meclisî Muhammed Bâkır b. Muhammed Takî (ö. 1110/1698). Zâdu'l-meâd. thk. Alauddin A'lamî. Beyrut: Müessesetu el-A'lamî li'l-Matbûât, 1423.

el-Mervezî, Ebû Talib İsmail b. Hüseyn Hüseyni (ö. 614/1217'den sonra). el-Fahrî fî ensâbi't-tâlibiyyîn. thk. Seyyid Mehdi er-Recâi. Kum: Mektebetü Âyetullah Mar'aşî Necefi, $1385 / 2007$.

Nîşâbûrî, Abdulhüseyin. Takvîm-i Şîa. Kum: İntişârât-1 Delîl-i Mâ, $1391 / 2012$.

Onat, Hasan. "Kerbelâyı Doğru Okumak". Akademik Orta Doğu. 2/ 1 (2007): 1-9. 
el-Ömerî, Necmeddin Ebi'1-Hasan Ali b. Muhammed b. Ali b. Muhammed el-Alevî (ö.466/1073). el-Mecdî fì ensâbi't-tâlibiyyîn. thk. Ahmed el-Mehdevî ed-Dâmeğânî. Kum: Mektebetü Âyetullah Mar'aşî Necefi, 1380/2001.

Schimmel, Annemarie. Tanri'nın Yeryüzündeki İşaretleri. İstanbul: Kabalc1 Yayınları, 2004.

Şeriati, Ali. Ali Şiası Safevi Şiası. çev. Hicabi Kırlangıç. Ankara: Fecr Yayınları, 2011.

Şeyh Tûsî, Ebû Cafer Muhammed b. el-Hasen (ö. 460/1067). Misbâhu'l-muteheccid. Beyrut: Müessese-i F1kh-1 Şîa, $1411 / 1990$.

Şeyh Tûsî, Ebû Cafer Muhammed b. el-Hasen (ö. 460/1067). el-Gaybe li'l-hucce. Kum: Dâru'l-Meârifi'l-İslâmî, 1411/1990.

Ünal, Mustafa. Dinlerde Kutsal Zamanlar. İstanbul: IQ Kültür Sanat Yayınları, 2008. 
